\title{
İlköğretim Matematik Öğretmen Adaylarının Değişim Oranı ile İlgili Düşünme Biçimlerinin Bir Modelleme Etkinliği Bağlamında İncelenmesi ${ }^{1}$
}

\author{
Mahmut Kertil $^{2}$, Ayhan Kürşat Erbaş ${ }^{3}$ ve \\ Bülent Çetinkaya $^{4}$
}

Makale geçmişi

Makale geliş tarihi: 28 Haziran 2016

Yayına kabul tarihi: 20 Mart 2017

Çevrimiçi yayın tarihi: 5 Nisan 2017

\begin{abstract}
Öz: Öğretmen adaylarının matematiksel modelleme konusunda mesleki bilgi ve becerilerini geliştirmeyi hedefleyen geniş kapsamlı bir çalışmanın parçası olarak, bu çalışmada nüfus artışını konu alan bir modelleme etkinliği bağlamında ilköğretim matematik öğretmen adaylarının "değişim oranı" kavramı üzerine düşünme biçimleri incelenmektedir. Çalışmanın katılımcılarını bir devlet üniversitesinin ilköğretim matematik öğretmenliği bölümünde son sınıfa devam eden 9 öğretmen adayı oluşturmaktadır. Bir matematiksel modelleme dersi kapsamında yapılan çalışmanın veri kaynaklarını; grup çalışmalarından derlenen yazılı raporlar ve çalışma kâğıtları, etkinlik sonrası düşünce raporları ve araştırmacı alan notları oluşturmaktadır. Bulgulara göre, çalışmanın katılımcıları "zamana bağlı nüfus artış oranı (hızı)" ifadesini yüzdelik ve eğim olmak üzere iki farklı şekilde yorumlamıştır. Öğretmen adaylarının yüzdelik yorumları daha yoğun olmakla birlikte modelleme etkinliği bağlamında nüfus verilerindeki yıl aralıklarının eşit verilmemesi bazı katılımcıları eğim yorumuna yönlendirmiştir. Ortaya çıkan bu iki farklı düşünme şekli, öğretmen adaylarının yüzdelik ve eğim yorumu arasındaki farkı ve bu ikisi arasındaki matematiksel ilişkiyi yorumlamada zorlandıklarını göstermektedir. Ayrıca "rate of change" kavramının Türkçe ifadesi ile ilgili problemli bir durum da gözlemlenmiștir. Çalıșmanın sonuçları, öğretmen adaylarının konu ile ilgili zorluklarının muhtemel kaynağı olan birimli oran ve birimsiz oran kavramları arasındaki fark dikkate alınarak tartışılmışıı.
\end{abstract}

Anahtar Kelimeler: Değişim oranı, birimli oran, birimsiz oran, yüzde, matematiksel modelleme, matematik öğretmen eğitimi

DOI: $10.16949 /$ turkbilmat.304212

\begin{abstract}
As a part of a larger study aiming at developing pre-service teachers' pedagogical knowledge about mathematical modeling, this study investigates pre-service elementary mathematics teachers' ways of thinking regarding rate of change in the context of a modeling task on population growth. The participants of the study were 9 prospective middle school mathematics teachers in their senior year attending a public university. The study was conducted as a part of an undergraduate course on mathematical modeling for prospective teachers. Data were collected through the prospective teachers' written group work and reports regarding their solution to the modeling activity, individual reflection papers, and researchers' field-notes. The results showed that participants demonstrated two different ways of thinking about the expression "rate of change in population with respect to time": (i) percentage of change in population, and (ii) per year change in population (slope). Even though "percentage" interpretation was dominant, some of the participants were directed to "per year change in population" interpretation as the year intervals in the problem context were not given with equal intervals. The results revealed about prospective teachers' difficulties in conceiving the difference and the mathematical relationship between "percentage" and "slope" interpretations. The results also revealed about the problematic aspect of expressing the term/concept "rate of change" in Turkish. As possible sources of these difficulties, the results are discussed in light of the distinction between rate and ratio.
\end{abstract}

Keywords: Rate of change, rate, ratio, percentage, mathematical modeling, mathematics teacher education

See Extended Abstract

\footnotetext{
${ }^{1} \mathrm{Bu}$ çalışma XII. Ulusal Fen ve Matematik Eğitimi Kongresinde (KTÜ, Trabzon) sunulan sözlü bildirinin genişletilmiş hali olup birinci yazarın doktora tezinin bir parçasıdır. Bu makaleye konu olan çalışma Türkiye Bilimsel ve Teknolojik Araştırma Kurumu (TÜBITTAK) tarafından $110 \mathrm{~K} 250$ nolu araştırma projesi kapsamında desteklenmiştir. Bu makalede öne sürülen görüşler yazarlara ait olup TÜBİTAK’’n görüşlerini yansıtmamaktadır. Ayhan Kürşat ERBAŞ, Türkiye Bilimler Akademisi Üstün Başarılı Genç Bilim İnsanlarını Ödüllendirme Programı (GEBİP) tarafından desteklenmektedir (A.K.E./TÜBA-GEBİP/2012-11).

${ }^{2}$ Öğr. Gör. Dr., Marmara Üniversitesi, AEF, Matematik ve Fen Bilimleri Eğitimi Bölümü, mkertil@marmara.edu.tr

${ }^{3}$ Prof. Dr., Orta Doğu Teknik Üniversitesi, Eğitim Fakültesi, Matematik ve Fen Bilimleri Eğitimi Bölümü, erbas@metu.edu.tr

${ }^{4}$ Doç. Dr., Orta Doğu Teknik Üniversitesi, Eğitim Fakültesi, Matematik ve Fen Bilimleri Eğitimi Bölümü, $\underline{\text { bcetinka@metu.edu.tr }}$
} 


\section{Giriş}

Değişim kavramı genel olarak tek bir değişken üzerinden yorumlanırken; değiş̧im oranı (hızl) kavramı iki değişkenin birbirleriyle ilişkili değişimlerinin (kovaryasyon) oranlanarak yeni bir nicelik olarak ifade edilmesi şeklinde yorumlanır. Basit olarak iki farklı değişkenin birbirleriyle ilişkili olarak nasıl değiştiğini niceliksel ve niteliksel olarak açıklamak için kullanılan "değişim oranı" kavramı, ileri düzey analiz konularında üzerinde işlemler yapılabilen ve bağımsız değişkendeki birim değişime karşılık fonksiyonun değerindeki değişim oranını ifade etmektedir (Thompson, 1994b). Fonksiyonlar, kovaryasyonel düşünme gerektiren durumlar, türev ve integral gibi analiz konularının daha iyi anlaşılabilmesi için öğrencilerin değişim oranı kavramını derinlemesine anlamaları önemlidir (Carlson, Jacops, Coe, Larsen \& Hsu, 2002; Cooney, Beckman \& Lloyd, 2010; Stroup, 2002; Thompson, 1994a). Değişim ve değişim oranı kavramlarının iyi anlaşılmaması öğrencilerin türev, integral ve diferansiyel denklemler gibi analiz konularında ve kavramlarında zorlanmalarının en önemli sebeplerinden birisi olarak ifade edilmektedir (Bezuidenhout, 1998; Rowland \& Javanoski, 2004; Thompson, 1994b; Ubuz, 2007; White \& Mitchelmore, 1996). Değişim oranı bir fonksiyonun kavramsal anlaşılmasına yardımcı olmanın yanı sıra, bağımlı ve bağımsız değişkenlerin kovaryasyonel olarak nasıl değiştiğinin doğasını açıklayarak o fonksiyonun hangi fonksiyon ailesine (doğrusal, ikinci dereceden, üstel, periyodik vs.) ait olduğunu da göstermektedir (Cooney ve ark., 2010). Ayrıca, değişim oranı, türev kavramının çoklu temsiller/gösterimler (örn., fiziksel, cebirsel ve geometrik) bağlamında ele alınarak daha iyi tanımlanması ve anlamlandırılması için önemli bir yere sahiptir (Bingölbali, 2008; Cooney ve ark., 2010; Delice ve Sevimli, 2016; Kendal \& Stacey, 2003; Taşar, 2010; Zandieh, 2000).

Örneğin, Şekil 1'de gösterilen Cooney ve arkadaşlarından (2010, s. 89) alıntılanan, değişim ve değişim oranı kavramının sınıf düzeylerine göre nasıl şekillendiğini gösteren, kenar uzunluğuna bağlı olarak karenin çevre uzunluğunun ve alanının nasıl değiştiği örneğini inceleyelim. Karenin kenarının her bir birimlik artışında meydana gelen kareleri çizerek yorumlama fiziksel yorumlama olup ilköğretim düzeyinde öğrencilerin sıklıkla başvurabileceği bir yöntemdir. Tablo ise bir kenar uzunluğunun her 1 birimlik değişiminde alan ve çevrenin nasıl değiştiğini nümerik olarak göstermektedir. Bu örnekte öğrenciler karenin kenar uzunluğunun her 1 birimlik değişimine karşllık çevre uzunluğunun 4 birim değiştiğini tablo ve grafik üzerinde gözlemleyerek bunun cebirsel olarak lineer bir fonksiyon olduğunu ve 4 değerinin de eğime karşılık geldiğini fark edebilirler. Benzer şekilde, kenar uzunluğunun birim değişimine karşıllk alandaki değişimin sabit oranda olmadığını aynı bağlamda inceleyerek lineer ve ikinci dereceden fonksiyonların değişim oranları bakımından nasıl farklılaştı̆̆ını gözlemleyebilirler. Bu ve benzeri örnekler, öğrencilerin niceliklerdeki değişimi ve eş zamanlı değişen niceliklerin değişim oranlarını farklı temsiller aracılı̆̆ı ile gözlemleyerek daha sağlam bir kavramsal anlamaya ulaşmasını sağlayabilir. Ancak, Confrey ve Smith'e (1994) göre değişim oranı kavramının toplamsal ve çarpımsal olmak üzere iki farklı yorumlanması vardır. Fonksiyondaki değişimin bağımsız değişkendeki değişime oranlanması değişim oranının toplamsal yorumudur. Bağımsız değişkendeki birim değişime karşılık bağımlı değişkenin 
kaç katına çıktığı veya yüzdelik olarak ne kadar değiştiği yorumu ise değişim oranının çarpımsal yorumudur (Confrey \& Smith, 1994).

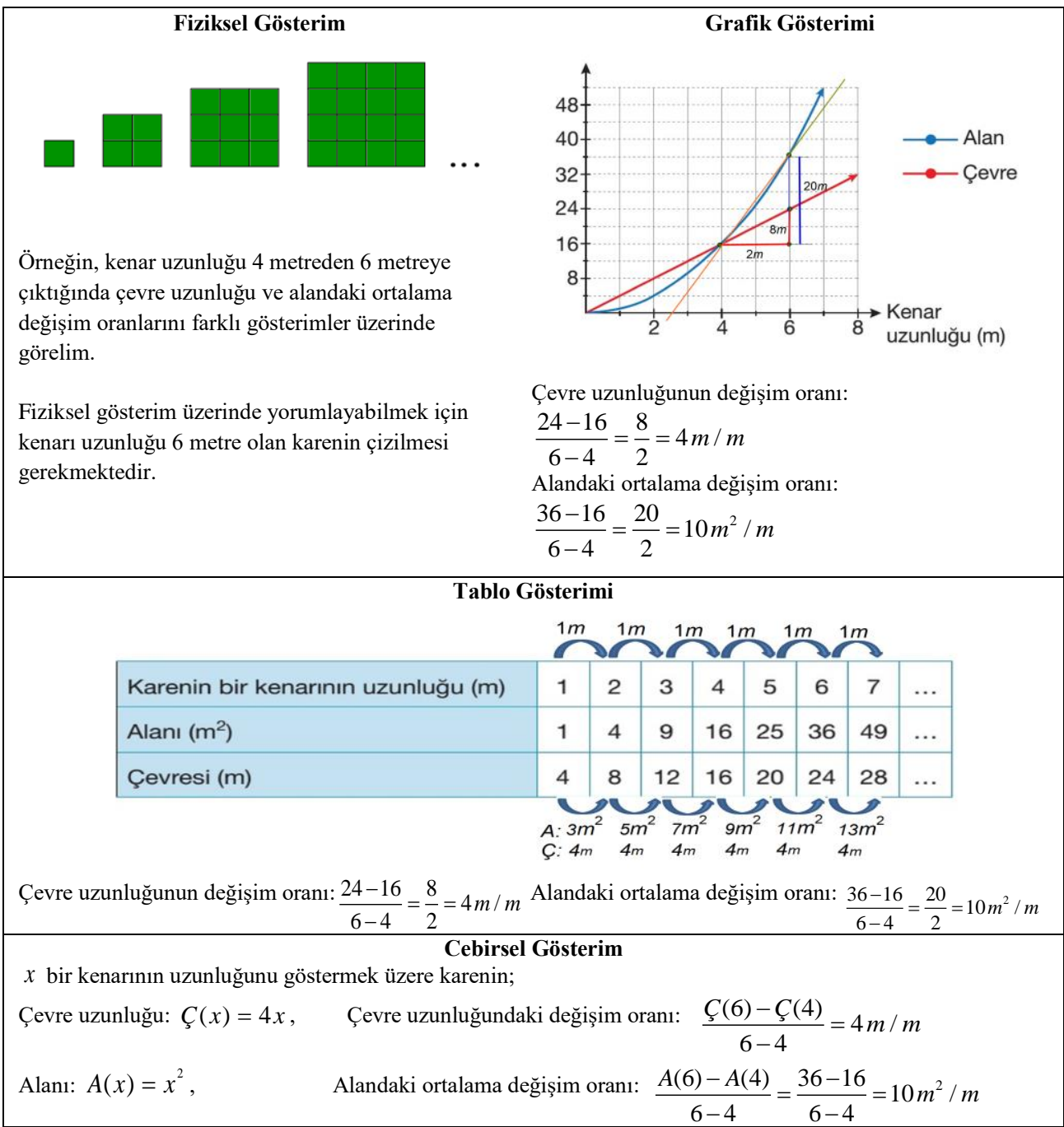

Şekil 1. Farklı fonksiyon temsilleri bağlamında değişim oranı kavramının yorumlanması (Cooney ve ark., 2010, s. 89)

Özellikle üstel fonksiyonlarla modellenebilen bağlamlarda değişim oranının bu iki farklı yorumu karşımıza çıkmaktadır. Bir problem durumunun analiz edilip 
yorumlanmasında bu iki yorumdan her biri farklı sonuçlar vereceğinden öğrencilerde değişim oranı kavramı ile ilgili bir kavram kargaşasına sebep olabilir. Örneğin, $f(x)=2^{x}$ fonksiyonu ile modellenen bir durumda, fonksiyonun herhangi bir noktadaki toplamsal değişim oranı (yani türevi) fonksiyonun değeriyle orantılı olarak değişmektedir $\left(f^{\prime}(x)=2^{x} \cdot \ln 2\right)$. Bu herhangi bir $x$ noktasında $f$ fonksiyonun anlık değişim oranının (hızının) $2^{x} \cdot \ln 2$ şeklinde ifade edilebileceği anlamına gelir. Çarpımsal anlamda düşünüldüğünde ise bu fonksiyonun değişim oranının sabit olması ve her bir adımda iki katına çıtığı yorumu ilk yoruma göre öğrenciler için daha kolay ve anlamlı olabilmektedir (Confrey \& Smith, 1994; Kertil, 2014).

Atfedilen önemine karşın değişim oranı kavramının anlaşılması ve farklı bağlamlarda yorumlanması öğretmenler ve öğrenciler için kolay değildir. Son dönemde yapılan ulusal ve uluslararası çalışmalar öğretmen ve öğrencilerin değişim oranı kavramını yorumlanma ve anlamlandırılmada zorluklar yaşadıklarını göstermektedir (Bezuidenhout, 1998; Coe, 2007; Gökçek ve Açıkyıldız, 2016; Gravemeijer \& Doorman, 1999; Herbert \& Pierce, 2008, 2012; Johnson, 2012; Orton, 1983; Taşar, 2010; Teuscher \& Reys, 2012; White \& Mitchelmore, 1996). Bu zorluklardan biri öğrencilerin (ortalama) değişim oranı kavramını farkların oranı olarak anlamlandıramamaları ve aritmetik ortalama kavramı ile karıştırmalarıdır (Bezuidenhout, 1998; White \& Mitchelmore, 1996). Öğrencilerin bir diğer zorluğu değişim oranı kavramını yalnız bağımlı değişkendeki değişim miktarıyla karıştırmalarıdır (Rowland \& Javanoski, 2004; Thompson, 1994a, 1994b; Zandieh \& Knapp, 2006). Bu durumun öğrencilerin değişim oranı kavramını yine kovaryasyonel olarak değişen iki değişkenin farklarının oranı olarak görememelerinden kaynaklandığ söylenebilir. Öğretmen ve öğrencilerde ortaya çıkan bir diğer zorluk ise değişim oranı kavramını sadece kinematik (hız-zaman) bağlamında görmüş olmaları ve başka bağlamlarda anlamlandıramamalarıdır (örn., Herbert \& Pierce, 2008, 2012; Wilhelm \& Confrey, 2003; Zandieh \& Knapp, 2006).

Değişim oranı kavramıyla ilgili öğrenci ve öğretmen zorluklarının muhtemel kaynakları olarak kavramın ders kitaplarında ve öğretim programlarında yeterince vurgulanmaması (Bingölbali, 2008), kavramın kinematik gibi kısıtlı bağlamlarda sunuluyor olmas1 (Gravemeijer \& Doorman, 1999; Thompson, 1994b; Zandieh \& Knapp, 2006) ve kovaryasyonel düşünme, eğim ve fonksiyon gibi bazı temel kavramlarla ilgili bilgi eksikliği (Herbert \& Pierce, 2008) gösteriliyor olmakla birlikte, ilgili alanyazında öğrenci ve öğretmenlerin değişim oranı kavramını nasıl algıladıkları ve kavramı anlamlandırmada yaşadıkları zorlukları muhtemel sebepleri ile birlikte daha farklı açılardan ortaya koyacak çalışmalara ihtiyaç duyulduğu da vurgulanmaktadır (örn., Ärleback, Doerr \& O’Neil, 2013; Bezuidenhout, 1998; Herbert \& Pierce, 2008).

Son dönemde, değişim oranı ile ilgili öğrenci ve öğretmen zorluklarını dikkate alarak bu kavramın gelişimine yönelik çalışmalar yapılmaya başlanmıştır. Bu çalışmalardan bazıları (örn., Ärleback ve ark., 2013; Doerr \& O’Neil, 2012; Doorman \& Gravemeijer, 2009; Herbert \& Pierce, 2008; Hoffkamp, 2011) değişim oranı kavramının kinematik dışında daha farklı bağlamlarda incelendiğinde öğrencilerin kavramsal anlamalarına 
olumlu katkı sağladığını göstermektedir. Doorman ve Gravemeijer (2009) ise bir öğretim deneyi çalışmasında bir gerçek hayat etkinliği kullanarak lise öğrencilerinin değişim, değişim oranı, hız ve bunun grafik gösterimi ile ilgili kavramsal gelişimini incelemiştir. Çalışmanın sonucunda, araştırmacılar öğrencilerin değişim oranını farkların oranı şeklinde ve grafik üzerinde değişkenlerin birimlerini kullanarak yorumlayabildiklerini ve kullandıkları dilin daha formel bir seviyeye yükseldiğini raporlamıştır.

Matematiksel modelleme etkinliklerini kullanarak yaptıkları tasarım-tabanlı bir çalışmada Doerr ve O’Neil (2012) lise öğrencilerinin değişim oranı kavramını sembolik, grafiksel ve cebirsel olarak anlamalarının geliştiğini raporlamıştır. Aynı çalışmada öğrencilerin üstel azalan fonksiyonlarda değişim oranı kavramını yorumlamada ve sözel olarak doğru ifade etmede zorlandıkları da gözlemlenmiştir. Bu araştırmanın devamı olarak yeni bir çalışmada lise öğrencilerinin değişim oranının negatif olduğu durumlarda değişimi ve değişim oranını doğru yorumlayamadıklarını gözlemleyen Ärleback ve arkadaşları (2013) üstel azalan fonksiyonlar üzerine daha farklı bağlamlarda öğrencilerdeki değişim oranı kavramının geliştirilmesine yönelik çalışmalar yapılmasını önermişlerdir. Bu çalışmalardan elde edilen sonuçlar değişim oranı kavramının; farkların oranı, oran, limit gibi formel matematiksel kavramlar ile ögretilmesinin yanında bu kavramın gerçek hayattan farklı bağlamlarda niteliksel olarak da hissettirilmesinin önemini ortaya koymaktadır. Diğer bir deyişle, değişim oranı kavramının farklı bağlamlarda ne anlama geldiğinin yorumlanması öğrenciler için formel matematikte kullanılan farkların oranı, limit ve eğim kavramlarını da daha anlamlı kılacaktır. Yukarıda bahsedilen bazı çalışmalarda da (örn., Ärleback ve ark., 2013; Doerr \& O’Neil, 2012) görüldüğü gibi değişim oranı kavramı matematiksel modelleme etkinlikleri kullanılarak farklı bağlamlarda ele alınabilir. Bu etkinliklerin kullanıldığı sınıf ortamları aynı zamanda sağladığı öğrenme imkânları ile farklı matematiksel düşünme biçimlerini ortaya çıkarmaya yardımcı olabilmektedir (Lesh \& Doerr, 2003). Bu nedenle modelleme etkinlikleri araştırmacıların da sıklıkla kullandığı ve oldukça zengin veri sağlayan araçlardır (Doerr \& Lesh, 2011; Lesh, 2010; Lesh, Cramer, Doerr, Post \& Zawojewski, 2003).

$\mathrm{Bu}$ çalışmada, öğretmen adaylarının değişim ve değişim oranı kavramını yorumlamaları ve düşünme biçimleri "Gelecek Yüzyılda Türkiye" başlıklı bir modelleme etkinliği bağlamında incelenmiştir. Çalışmanın tek bir modelleme etkinliği kapsamında incelenmiş olması bir sınırlılık olarak değerlendirilebilse de modelleme etkinliklerinin doğası gereği bu modelleme etkinliği öğretmen adaylarının farklı düşünme biçimlerini ortaya çıkartmaya ve kavramla ilgili temel zorluklarını belirlemeye yönelik zengin bir veri toplama ortamı sağlamıştır. Nitekim modelleme etkinlikleri bu özellikleriyle bilinmektedir (Doerr \& Lesh, 2011; Lesh, 2010; Yoon, Dreyfus \& Thomas, 2010). Modelleme etkinliğinin bağlamı Türkiye Cumhuriyeti nüfusunun yıllara göre değişiminin incelenmesiyle ilgilidir ve etkinlik değişim oranı kavramını kinematik dışında bir bağlamda sunmanın yanı sıra üstel fonksiyon fikrini de içermektedir. Üstel fonksiyon içeren durumlarda değişim oranı kavramını anlamlandırmanın öğrenciler için daha zor 
olduğu ve bu konu üzerinde araştırmalar yapılmasının gerekliliği bazı araştırmacılar tarafindan ifade edilmişti (örn., Ärleback ve ark., 2013; Confrey \& Smith, 1994). Dolayısıyla, bu çalışmanı amacı nüfus artışı teması çerçevesinde kurgulanan ve üstel fonksiyon fikrini barındıran bir modelleme etkinliği bağlamında öğretmen adaylarının değişim oranı kavramını nasıl yorumladıkları ve ne tür fikirler geliştirdiklerini incelemektir. Çalışmaya yön veren araştırma soruları şunlardır:

1. Matematik öğretmen adaylarının "Gelecek Yüzyılda Türkiye" başlıklı bir modelleme etkinliği bağlamında değişim ve değişim oranı kavramları ile ilgili düşünme biçimleri (yapıları) nasıldır?

2. Matematik öğretmen adaylarının "Gelecek Yüzyılda Türkiye" başlıklı bir modelleme etkinliği bağlamında değişim oranı ile ilgili ne tür zorlukları ve kavram yanılgıları ortaya çıkmıştır?

\subsection{Değişim Oranı Kavramı ve Okul Matematiği}

Değişim oranı kavramı ileri düzey analiz konularının anlaşılabilmesi için anahtar kavram niteliğindedir (Carlson ve ark., 2002; Cooney ve ark., 2010; Thompson, 1994a). Örneğin, türev konusu bağlamında öğrencilerin değişim oranı kavramı bilgilerinin eksik olduğu, ilgili kaynakların bu konuya yeterince vurgu yapmadığı ve öğrencilerde türevin değişim oranı yorumunun kayıp bir halka olduğu belirtilmektedir (Bingölbali, 2008). Nitekim Orton (1983), İngiltere'de lise öğrencileri ve öğretmen adaylarının ikinci dereceden bir fonksiyonun belirli bir noktadaki değişim oranı sorusunu anlamlandıramadıklarını ve cevaplayamadıklarını gözlemlemiştir. Benzer şekilde, White ve Mitchelmore da (1996) Avustralyalı öğrencilerin değişim oranı kavram bilgilerinin işlemsel düzeyde ve günlük hayatla ilişkisi olmayan problem bağlamlarıyla sınırlı olduğunu gözlemlemiştir. Yine Türkiye'de yapılan çalışmalarda da öğrencilerin büyük çoğunluğunun “ $f(x)=x^{2}-7 x$ fonksiyonunun $x=3$ noktasındaki değişim oranı nedir?" gibi soruları anlamlandırmada ve türevle ilişkisini kurmakta zorlandıkları gözlenmiştir (örn., Bingölbali, 2008; Gökçek ve Açıkyıldız, 2016). Son yıllarda farklı ülkelerde yapılan çalışmalarda da öğrencilerin türevin değişim oranı kavramıyla yorumlamada zorluklarının devam ettiğini ortaya koymaktadır (örn., Bezuidenhout, 1998; Herbert \& Pierce, 2012; Gökçek ve Açıkyıldız, 2016; Johnson, 2012; Teuscher \& Reys, 2012; Ubuz, 2007). Nitekim Gökçek ve Açıkyıldız'ın (2016) çalışmasında ortaya çıkan matematik öğretmen adaylarının limit, anlık değişim oranı, ortalama değişim oranı ve türev kavramları arasında doğru bir ilişkilendirme yapamadıkları bulgusu ülkemizde de benzer durumun olduğunu göstermektedir. Bu çalışmalar türevin değişim oranı yorumu ve değişim oranı ifadesinin anlamlandırılması ile ilgili öğrenci ve öğretmen zorluklarının farklı ülkelerde ortak bir sorun olarak ortaya çıktığını göstermekte olup bunun epistemolojik bir sorun olma ihtimalini akla getirmektedir (Bingölbali, 2008).

Ders kitapları veya diğer öğretim materyallerinde değişim oranı kavramının sunulduğu bağlam, bu kavramın anlamlandırılması ile ilgili zorluğun önemli sebeplerinden birisidir (Gravemeijer \& Doorman, 1999; Yoon ve ark., 2010). Türevin değişim oranı yorumu ile ilgili öğretim materyallerinde (ders kitabı, müfredat vb.) çoğunlukla hareket bağlamı 
kullanılmakta; hız ise değişim oranı kavramı için prototip olarak sunulmaktadır (Herbert \& Pierce, 2008). Hareket bağlamı türev gibi temel analiz konularının tarihsel gelişiminde asıl çıkış noktası niteliği taşımakla birlikte, sadece bu bağlama bağımlı kalınması öğrencilerin değişim oranını farklı bağlamlarda anlamlandıramamasına sebep olmaktadır (Gravemeijer \& Doorman, 1999; Herbert \& Pierce, 2008; Yoon ve ark., 2010). Örneğin, suyla doldurulan bir depodaki su miktarına bağlı olarak su seviyesini/yüksekliğini gösteren bir grafik (bağımlı değişken yükseklik, bağımsız değişken hacim) üzerinde öğrenciler değişim oranının ne anlama geldiğini yorumlamakta zorlanmışlardır (Carlson ve ark., 2002). Benzer şekilde, matematik öğretmen adayları yüksekliğe bağlı açık hava basıncını gösteren bir grafik üzerinde bir noktadaki anlık değişim oranının ve iki nokta arasındaki ortalama değişim oranının ne anlama geldiğini yorumlamakta zorlanmışlardır (Kertil, 2014). Bu nedenle, değişim oranı kavramının öğretiminde hareket (kinematik) bağlamının yanı sıra bağımsız ve bağımlı değişkenleri sırasıyla örneğin hacim-yükseklik, yükseklik-açık hava basınc1, ürün miktarı-maliyet, hız-yakıt tüketimi olan farklı bağlamların ve örneklerin kullanılması oldukça önemlidir. Örneğin, ürün miktarına bağlı maliyet değişimini inceleyen bir fonksiyon bağlamında, değişim oranının "ürün miktarının birim artışına karşılık gelen maliyet" veya "ilave bir birim malın üretim maliyeti" anlamına geldiğini ve bunun da ekonomide "marjinal maliyet" terimiyle ifade edildiği vurgulanabilir.

Değişim oranı kavramının anlaşılması ile ilgili zorlukların bir diğer sebebi olarak öğretmen ve öğrencilerin bu kavramın temeli olan eğim (Stump, 1999) ve (birimli ve/veya birimsiz) oran gibi kavramlarla ilgili bilgilerinin eksikliği gösterilmektedir (Thompson, 1994b). İlköğretim düzeyinden başlayarak öğretile gelen oran-orantı konusu da değişim oranı kavramının altyapısı niteliğindedir (Akar, 2009).

순 "Bir kişi 45 dakikada kitabının 30 sayfasını okuyor." ifadesinde okunan sayfa sayısının geçen süreye oranı; $\frac{30 \text { sayfa }}{45 \text { dakika }}=\frac{30}{45}$ sayfa / dakika olarak yazıldığından bu oran birimlidir.

通 Yüklü bir kamyonun 4,6 tonluk kütlesinin 3,5 tonluk darasına oranı; $\frac{4,6}{3,5} \frac{\text { ton }}{\text { ton }}=\frac{4,6}{3,5}$ olarak yazılır ve bu oran birimsizdir.

Şekil 2. İlköğretim (6-8. sınıflar) Matematik Dersi Öğretim Programı'nda "birimli oran” ve "birimsiz oran" farkını belirtmek için kullanılan açıklamalar (Talim Terbiye Kurulu Başkanlığ1 [TTKB], 2009, s. 153)

2009 yılındaki İlköğretim Matematik Dersi Öğretim Programı incelendiğinde "oranorantı" konusunun ilk olarak 6. ve 7. sinıflarda verildiği görülmektedir (bkz. TTKB, 2009). 6. sınıf Matematik Dersi Öğretim Programı'nda oran kavramı birimsiz oran (ratio) ve birimli oran (rate) olmak üzere iki farklı terminoloji kullanılarak ifade edilmektedir. Öğretim programında öğrencilerin nicelikleri karşılaştırmada oran kavramını kullanması ve oranı farklı biçimlerde göstermesi beklenirken, birimli ve birimsiz oran arasındaki fark 
ise Şekil 2'de gösterilen örneklerle açıklanmaktadır. 2013 yılında yürürlüğe giren 5-8. sınıflar Ortaokul Matematik Dersi Öğretim Programı incelendiğinde de benzer durum karşımıza çıkmaktadır (TTKB, 2013a, s. 17). Şekil 3’te görüldüğ̈̈ üzere bu öğretim programında da birimli ve birimsiz oran terimleri kullanılmakta ve bu iki kavram arasındaki fark, önceki öğretim programındakine benzer örneklerle açıklanmaktadır.

6.1.6.3. Aynı veya farkıı birimlerdeki iki çokluğun birbirine oranını belirler.

- Örneğin, 3 saatte $150 \mathrm{~km}$ giden bir aracın aldığı yolun geçen süreye oranı $\frac{150 \mathrm{~km}}{3 \mathrm{sa}}=50 \mathrm{~km} / \mathrm{sa}$ olarak yazıldığından bu oran birimlidir. $6 \mathrm{~A}$ sınıfının topladığı plastik kapakların sayııının 6B sınıfının topladığı plastik kapakların sayısına oranı $\frac{180 \text { adet }}{120 \text { adet }}=\frac{3}{2}$ olarak yazılır ve bu oran birimsizdir.

- Birimli oranlardan sürat birimi olan $\mathrm{km} / \mathrm{sa}$. ile $\mathrm{m} / \mathrm{sn}$. arasında dönüşümler yapilır.

Şekil 3. Ortaokul (5-8. sınıflar) Matematik Dersi Öğretim Programı'nda “birimli oran” ve "birimsiz oran" farkını açıklamak için kullanılan açıklamalar (TTKB, 2013a, s. 17)

Birbirini takip eden bu iki öğretim programında da 6. sınıf kazanımları kapsamında birimli ve birimsiz oran açıklanmış olmakla birlikte 2011 yılındaki Ortaöğretim (9-12. sinıflar) Matematik Dersi Öğretim Programı ve 2013 yılında yürürlüğe giren Ortaöğretim (9-12. sinıflar) Matematik Dersi Öğretim Programı'nda ise oran-orantı konusunun ele alındığı kısımlarda oran kavramı için birimli-birimsiz ayrımına hiçbir vurgu yapılmamıştır. Bununla birlikte, birimli-birimsiz oran ile ilgili Türkiye'deki matematik dersi öğretim programlarındaki açıklamalar türev kavramının doğru yorumlanabilmesini zorlaştırabilmektedir. Thompson'a (1994b) göre, çoklukların aynı ya da farklı birimlerde olmasına bakılmaksızın, statik değerlerin oranlanmasının birimsiz oran (ratio), dinamik ve sürekli değişen değerlerin oranlanmasının birimli oran (rate) olarak açıklanması türev kavramının doğru yorumlanabilmesi için daha uygundur.

Türev konusu bağlamında birimli oran (rate) kavramı 2011 y1lında yayınlanan Ortaöğretim Matematik Dersi Öğretim Programı'nda türev kavramının gerçek hayatta yorumlanması (bkz. Şekil 4) bağlamında ele alınmaktadır. Öğretim programında, İngilizcede "rate of change (increase)" olarak ifade edilen kavram "artış hızı" terimi ile ifade edilmektedir. Diğer bir deyişle öğretim programında "rate (birimli oran)" yerine "hız" kavramının/ifadesinin kullanıldığı görülmektedir. 
"En son işsizlik rakamları, ekonomik durgunluğun en üst noktasına yaklaşmakta olduğuna ilişkin tahminleri doğrular şekildedir. İşsizlik, artmaya devam etmesine rağmen artış hızı öncekinden daha azdır."

Yukarıdaki gazete haberi türev yardımıyla aşağıdaki gibi yorumlatılır:

$y$, herhangi bir $t$ anındaki işsiz sayısını gösteren türevlenebilir bir fonksiyondur. İşsizliğin değişme hızı $\frac{d y}{d t}$ dir. ... Ancak artış hızı yani $\frac{d y}{d t}$ nin kendisi azalmaktadır. (“... artış hızı öncekinden daha azdır.") Bu nedenle $\frac{d y}{d t}$ fonksiyonu azalan bir fonksiyondur...

Şekil 4. Ortaöğretim (9-12. Sınıflar) Matematik Dersi Öğretim Programı'nda türevin günlük hayat yorumu (TTKB, 2011, s. 312)

2013 yılında yenilenen Ortaöğretim Matematik Dersi Programı incelendiğinde ise türev kavramı "değişim oranı" ve "anlık değişim oranı" terimleriyle ifade edildiği görülmektedir (bkz. Şekil 5). Burada kullanılan "oran” kelimesi İngilizcede "rate" ifadesinin yerine kullanılmış olup bu iki kelime anlam olarak birbirini tam karşılamamaktadır. Diğer yandan 2009 ve 2013 ilköğretim/ortaokul matematik dersi öğretim programlarında (TTKB, 2009, 2013a) "rate" yerine birimli oran teriminin kullanıldığını hatırlayalım. Bu durum, ortaokul ve lise düzeyindeki matematik dersi öğretim programlarında aynı kavram için kullanılan terimde bir tutarlılık sağlanmadığını göstermektedir. Oran kavramının kavramsal boyutu, öğretim programları ve ders kitaplarında ele alınış biçimiyle ilgili daha kapsamlı bir bilgi için Akar'ın (2009) çalışmasına bakılabilir.

\section{ID.12.1.2. Türev}

Terimler: Değişim oranı, anlık değişim oranı, türev

Sembol ve Gösterimler: $f^{\prime}(x), f^{\prime \prime}(x), \frac{d y}{d x}, \frac{d^{2} y}{d x^{2}}$

iD.12.1.2.1. Fizik ve geometri modellerinden yararlanarak değişim oranı kavramını açıklar. [V] Anlık değişim oranı kavramı açıklanarak, anlık değişsim oranına türev denildiği belirtilir.

Şekil 5. Ortaöğretim (9,10,11 ve 12. sınıflar) Matematik Dersi Öğretim Programı'nda türevin değişim oranı yorumu (TTKB, 2013b, s. 46)

Özet olarak, yukarıda bahsedilen çalışmalar değişim oranı kavramının anlaşılması ve anlamlandırılması ile ilgili tutarlı ve bütüncül bir yaklaşımın olmadığını ortaya koymaktadır. Bu sorunun muhtemel sebepleri olarak değişim oranı kavramının gerçek 
hayat yorumlarının genelde hareket (kinematik) bağlamıla sınırlandırılarak verilmesi ve oran, eğim gibi daha temel kavramlarla ilgili öğrencilerin bilgi eksikliklerinin olabileceği vurgulanmaktadır (örn., Bezuidenhout, 1998; Gravemeijer \& Doorman, 1999; Herbert \& Pierce, 2008, 2012; Johnson, 2012; Teuscher \& Reys, 2012). Alanyazındaki bu bulgular dikkate alınarak bu çalışmada, hareket bağlamı haricinde bir gerçek hayat durumunun matematiksel modellenmesi sürecinde öğretmen adaylarının değişim ve değişim oranı kavramları ile ilgili düşünme biçimleri incelenmiştir.

\subsection{Kuramsal Çerçeve}

Bu çalışmanın veri toplama ve verilerin yorumlanması sürecinde Model ve Modelleme Yaklaşımı (MMY) (Doerr \& Lesh, 2011; English, 2003; Lesh, 2010; Lesh \& Doerr, 2003; Lesh, Doerr, Carmona \& Hjalmarson, 2003; Lesh \& Harel, 2003) kuramsal çerçeve olarak kullanılmıştır. MMY'ye göre matematiksel düşünme sürecinde öğrencilerin kullandıkları zihinsel araçların tamamı zihinsel modeller olarak adlandırılmaktadır. Modeller farklı gösterim sistemleriyle dış dünyaya aktarılan, başka karmaşık sistemleri oluşturma, tanımlama ve açıklama sürecinde kullanılan, kuralları, işlemleri, ilişkileri ve daha farklı yapıları içeren zihindeki kavramsal sistemlerdir (Lehrer \& Schauble, 2007; Lesh \& Doerr, 2003). Modelleme ise olayları ve problemleri yorumlama (tanımlama, açıklama veya oluşturma) sürecinde problem durumlarını zihinde düzenleme, koordine etme, sistemleştirme ve organize edip bir örüntü bulma, zihinde farklı şemalar ve modeller kullanma ve oluşturma sürecidir (Lesh \& Doerr, 2003; Sriraman, 2006). Bu bağlamda "model" bir süreç sonunda oluşturulmuş ürünü ifade ederken; "modelleme" ise bir durumun fiziksel, sembolik ya da soyut modelini oluşturma sürecini ifade etmektedir (Sriraman, 2006).

Model ve Modelleme Yaklaşımı'nda genel anlamda model-oluşturma (model-eliciting) etkinlikleriyle öğrencilere belirli matematiksel kavram ve modellerin tarihsel gelişimindeki doğal süreci yaşatılarak onlarda bu kavramları ihtiyaç olarak hissettirme ve sezgisel olarak ortaya çıkarma amaçlanmaktadır (Doerr \& Lesh, 2011; Lesh \& Doerr, 2003; Lesh \& Harel, 2003). MMY'ye göre model-oluşturma etkinlikleri çok farklı bağlamlarda, farklı gruplarla farklı amaçlar için kullanılabilir (Doerr \& Lesh, 2011; Lesh, 2010; Lesh ve ark., 2003). Örneğin model-oluşturma etkinlikleri, içerdiği matematiksel modeller ve kavramlarla ilgili öğrencilerin düşünme süreçlerini inceleme, belirli matematiksel modellerin ve kavramların öğrencilerde sezgisel olarak nasıl geliştiğini gözlemleme gibi araştırmaları yapabilmek için kullanılabilmektedir. Model-oluşturma etkinlikleri bu anlamda araştırmacılar için zengin birer veri toplama ortamı sağlamaktadır (Doerr \& Lesh, 2011; Lesh, 2010). Nitekim, araştırmacıların son yıllarda MMY ve modeloluşturma etkinlikleri kullanarak farklı sınıf seviyelerinden öğrencilerin veya öğretmen adaylarının matematiksel düşünme biçimlerini ve kavramsal gelişimlerini incelemeye başladıkları görülmektedir (örn., Ärleback ve ark., 2013; Doerr \& O’Neil, 2012; Kertil, 2014; Lesh, 2010; Yoon ve ark., 2010). Bu çalışmalarda genellikle tasarım-tabanlı araştırma veya özel durum çalışması desenlerinin kullanıldığı görülmektedir (örn., Ärleback ve ark., 2013; Lesh, 2010; Yoon ve ark., 2010). 
Model-oluşturma etkinlikleri araştırma amacının yanı sıra ilgili kişilerin matematiksel bilgi ve becerilerin geliştirilmesi amacıyla da kullanılmaktadır. Örneğin, zengin matematiksel fikirlerin üretilmesine ve farklı çözüm yaklaşımlarının geliştirilmesine firsat veren bu etkinliklerin öğretmen eğitiminde kullanılmasının öğretmen adaylarının hem alan bilgisinin hem de pedagojik alan bilgisinin gelişimine katkı sağlayacağı öngörülmektedir (Schorr \& Lesh, 2003). Aslında öğretmen adaylarının model-oluşturma etkinliklerini birer öğrenci gibi çözüp, modelleme süreçlerini deneyimlemeleri ve süreç sonunda diğer öğretmen adayları ile matematiksel düşünce ve modellerini paylaşıp tartışmaları onların matematiği öğretme bilgilerinde gelişim sağlamaktadır (Doerr \& Lesh, 2011; Lesh \& Doerr, 2003; Lesh \& Lehrer, 2003; Schorr \& Lesh, 2003). Bu çalışmada Gelecek Yüzyılda Türkiye başlıklı bir model-oluşturma etkinliği kullanılarak öğretmen adaylarının değişim ve değişim oranı kavramları ile ilgili düşünme biçimleri incelenmiş ve bulgular etkinlik bağlamında yorumlanmıştır.

\section{Yöntem}

\subsection{Araştırma Bağlamı}

$\mathrm{Bu}$ çalışma, tasarım-tabanlı araştırma deseni (Kelly, 2004; Lesh, Kelly ve Yoon, 2008) kullanılarak, öğretmen adaylarının matematiksel modelleme ve sınıf uygulamaları konusunda pedagojik bilgi ve becerilerini geliştirmeyi hedefleyen lisans düzeyinde "Öğretmenler için Matematiksel Modelleme" başlıklı bir dersin tasarımı ve dersin birkaç kez yinelenerek uygulamasının yapıldığı geniş kapsamlı bir araştırmanın bir parçasını oluşturmaktadır. Haftada 3 saat olmak üzere 13 haftalık bir ders kapsamında öğretmen adaylarının matematiksel model ve modellemenin ne olduğu, modelleme sorularının doğası ve çözüm süreci, öğretmenin rolü, grup çalışmasının önemi, modelleme uygulamalarında ortaya çıkan öğrenci düşünme şekilleri, modelleme uygulamalarında teknoloji kullanımı, modelleme sorusu geliştirme ve uygulama gibi konu ve temalarda bilgi ve becerilerini geliştirmeleri hedeflenmiştir. Bu hedeflere yönelik olarak ders kapsamında yapılan ana faaliyetler şunlardır: (i) modelleme etkinliklerinin grup çalışması ile çözülmesi, (ii) çözülen modelleme etkinliklerinden bazıları ile ilgili lise öğrencilerinin çözümlerinin ve matematiksel düşünme şekillerinin incelenmesi, (iii) modelleme etkinliklerinin doğası ve diğer problem türleri ile karşılaştırılması; modelleme süreci ve bu süreçte grup çalışmasının önemi ve öğretmenin rolü; modelleme-teknoloji ilişkisi konularında yansıtıcı düşünme çalışmaları yapılması. Bu çalışmada ders kapsamında uygulanan modelleme etkinliklerinden biri olan ve dersin 6 . haftasında ele alınan Gelecek Yüzyılda Türkiye (bkz. Ek-1) başlıklı modelleme etkinliğinin çözüm sürecinde öğretmen adaylarının değişim ve değişim oranı kavramları ile ilgili düşünme biçimleri incelenmiş ve yorumlanmıştır.

Gelecek Yüzyılda Türkiye başlıklı modelleme etkinliği, model-oluşturma etkinliği prensipleri (Lesh, Hoover, Hole, Kelly \& Post, 2000) göz önünde bulundurularak Erbaş ve arkadaşları (2016) tarafından geliştirilmiştir. Değişim ve değişim oranı kavramlarının hareket (hız-zaman) bağlamı dışındaki bir gerçek hayat bağlamında, yıllar bazında 
Türkiye Cumhuriyeti nüfus verileri kullanılarak yorumlatılmasının hedeflendiği bu etkinlik iki bölümden oluşmaktadır. Etkinliğin ilk bölümü değişim kavramı ile ilgili olup ikinci bölümü zamana bağlı değişim oranı kavramıyla ilgilidir. Etkinlikte "nüfus artış oranı" ifadesinin öğrencilere anlamlı gelmeyebileceği düşüncesiyle öğretim programlarında türev konusu bağlamında kullanılan "hız" ifadesine de parantez içerisinde yer verilmiştir. Ayrıca, etkinlikte nüfus verilerinde yıllar 1, 5, 7 ve 10 yıl aralıklarında değişecek şekilde verilmiş ve katılımcıların farklı yıl aralıklarını karşılaştırabilmeleri için ortalama nüfus artış oranı matematiksel kavramına yönlenmelerini sağlamak amaçlanmıştır. Cooney ve arkadaşlarına (2010) göre farklı problem bağlamlarında zaman aralıkları genellikle eşit ve bir birim artırılarak verildiği için öğrencilerde (ortalama) değişim oranı kavramının matematiksel anlamı tam olarak gelişmemektedir. Örneğin, 1 saat aralıklarla aracın gittiği yolu gösteren bir grafikte aracın "birim zamanda (1 saat, 1 dakika vb.) aldığı yol" ifadesi, karşılığını grafikte kolayca bulmaktadır. Ancak, aralıklar eşit verilmediği zaman, öğrencinin karşılaştırma yapabilmesi için bir standartlaştırmaya gitmesi, yani aralıklardaki ortalama değişim oranına odaklanması gerekmektedir.

Çalışmada, öğretmen adaylarının Gelecek Yüzyılda Türkiye modelleme etkinliği özelindeki düşünme biçimlerine odaklanıldığından nitel araştırma yöntemlerinden özel durum çalışması kullanılmıştır (Cohen, Manion \& Morrison, 2000). Çalışmada sınıf içerisinde oluşturulan üç grup farklı durumlar olarak incelenmiş ve elde edilen bulgular bütüncül olarak bütün sınıf/katılımcılar için yorumlanmıştır (Yıldırım ve Şimşek, 2006). Ders kapsamında kullanılan diğer modelleme etkinlikleri değişim oranı kavramını içermediğinden bu etkinlikten önce üzerinde çalışılan diğer modelleme etkinliklerinin çalışmaya katılan öğretmen adaylarının düşünme biçimlerine bir etkisinin olmadığ varsayılmaktadır.

\subsection{Katılımeılar}

Çalışmanın katılımcılarını bir devlet üniversitesinin ilköğretim matematik öğretmenliği programı son sınıf öğrencilerinden Öğretmenler için Matematiksel Modelleme dersine devam eden 9 (5 k1z, 4 erkek) ilköğretim matematik öğretmen adayı oluşturmaktadır. Öğretmen adayları dönem boyunca sınıf içi çalışmaları üçerli gruplar halinde yapmışlardır. Katılımcılardan ikisi yabancı uyruklu olup iyi düzeyde İngilizce bilmekte ve Türkçe konuşmakta zorlansa da konuşulanları anlayabilmektedir. Tüm katılımcılar başta Analiz-1 ve Analiz-2 dersleri olmak üzere çeşitli matematik ve matematik eğitimi derslerini çalışma öncesinde almış ve başarıyla tamamlamışlardır.

\subsection{Modelleme Etkinliğinin Uygulanması ve Veri Toplama Süreci}

Öğretmen adayları, Öğretmenler için Matematiksel Modelleme dersi kapsamında bir dönem boyunca üçerli gruplarla yedi modelleme etkinliği üzerinde çalışmışlardır. Gelecek Yüzyılda Türkiye başlıklı modelleme etkinliği dersin 6 . haftasında uygulanmıştır. $\mathrm{Bu}$ etkinlikten önce öğretmen adayları farklı konu ve kavramlar içeren üç modelleme etkinliği üzerinde çalışmışlardır. Modelleme etkinliklerinin uygulanmasında süreç ve zaman tanzimi genel olarak şu şekilde gerçekleşmiştir: (i) bireysel çalışma (5 dakika), (ii) grup çalışması (70 dakika), (iii) çözümlerin sınıf ortamında sunulması ve sınıf tartışması (15 
dakika). Buna göre öğretmen adayları ilk olarak 5 dakika boyunca bireysel olarak etkinliği okuyup anlamaya çalışmışlar ve daha sonra üçerli gruplar halinde etkinlik üzerinde çalışmaya devam etmişlerdir. Öğretmen adaylarına kısa da olsa etkinlik üzerinde bireysel çalışma yaptırılarak onların etkinlik üzerinde yeterince düşünmeleri ve grup çalışmasına kendi fikirleri ile gelmeleri amaçlanmıştır. Grup çalışmaları tamamlandıktan sonra grup çalışma kâğıtları ve raporları toplanmış ve her bir grubun çözümünü sunarak sınıf tartışmasına katılması sağlanmıştır.

Öğretmenler için Matematiksel Modelleme dersi üçüncü yazar tarafından yürütülmüş olup birinci yazar bütün derslere, ikinci yazar ise bazı derslere gözlemci olarak katılmıştır. Dersi yürüten araştırmacı modelleme etkinliklerinin uygulanması sürecinde doğrudan değerlendirme içeren geri bildirimlerden (örn., Doğru, Yanlış vb.) kaçınarak öğretmen adaylarının neler düşündüklerini açık uçlu sorularla (örn., Nasıl düşündünüz? Neden, açıklayabilir misiniz? vb.) ortaya çıkarmaya çalışmıştır. Diğer araştırmacılar ise etkinlik uygulanma sürecinde ve sınıf tartışması esnasında sadece gözlemci olarak alan notu tutmuşlardır.

Çalışmanın veri kaynaklarını öğretmen adaylarının modelleme etkinliği ile ilgili çözümlerini içeren çalışma kâğıtları ve yazılı raporlar, öğretmen adaylarının bireysel olarak hazırladıkları etkinlik sonrası düşünce raporları ve araştırmacı alan notları oluşturmaktadır. Etkinlik sonrası düşünce raporunda, her bir katılımcıdan etkinlik sürecinde yaşadıklarını tekrar düşünerek grup tartışmalarında öne çıkan fikirleri, bu fikirlerin nasıl geliştiğini, nasıl fikir birliğine vardıklarını, zorlandıkları noktaları, sonraki uygulamalar için bu etkinliğin nasıl geliştirilebileceği ve uygulanabilirliğiyle ilgili varsa önerilerini mümkün olduğu kadar detaylı ve örneklendirerek açıklamaları istenmiştir. Elektronik ortamda yazdırılan yansıtıcı düşünme raporları ile öğretmen adaylarının etkinlikle ilgili düşünceleri, varsayımları, problemi nasıl çözdükleri ve hangi yöntemleri kullandıkları konularında derinlemesine bilgi edinilmesinin yanında grup içi tartışma ve çözüm süreçlerinin grubun her bir üyesinin gözünden nasıl algılandığ 1 anlaşılmaya çalışılmıştır. Çalışmada kullanılan materyallerin hem İngilizce hem de Türkçe sürümleri tüm katılımcılara verilmiş olup yabancı uyruklu öğretmen adaylarının bulunduğu grupta tartışmalar İngilizce yürütülmüş ve grup raporları İngilizce hazırlanmıştır.

\subsection{Veri Analizi}

Çalışmada elde edilen veriler nitel analiz yöntemlerinden içerik analizi yöntemi kullanılarak analiz edilmiştir (Yıldırım ve Şimşek, 2006). Veri analizine başlamadan önce, Confrey ve Smith (1994) ve Thompson'ın (1994b) değişim oranı kavramına yönelik öğrencilerin muhtemel düşünme biçimleri ile ilgili çalışmaları çerçevesinde veri analizinde kullanmak üzere (i) eğim yorumu ve (ii) yüzdelik yorum olmak üzere iki ana kategori belirlenmiştir. Veri analizi sürecinde öncelikli olarak her bir grup için grup çalışma kâğıtları ve grup raporları ayrıntılı olarak her bir araştırmacı tarafından ayrı ayrı incelenerek katılımcıların değişim oranı kavramına yönelik düşünme biçimleri bu iki ana kategori bağlamında yorumlanmıştır. Grup raporları her bir grubun nihai çözümünü 
gösterdiği için grup çalışmalarında ortaya çıkan düşünme ve tartışma süreçlerini daha iyi anlamak, grup çözüm raporunda yazılmayan önemli tartışma noktalarını ve fikir akışını yakalamak için daha sonra etkinlik sonrası düşünme raporları ve alan notları da incelenmiştir. Çalışma kâğıtları ve grup raporları kullanılarak yapılan kodlamalar ve yorumlamalar her bir grup üyesinin etkinlik sonrası düşünme raporlarından ve alan notlarından gelen veriler çerçevesinde test edilmiştir. Tüm verilerin kodlanmasından sonra araştırmacılar bir araya gelerek kodlamaları karşılaştırmış, farklı kodlamalar üzerinde tartışmış ve fikir birliğine varmışlardır. Analizler sonucunda elde edilen bulgular katılımcıların çözümlerinden örnekler ve etkinlik sonrası düşünme raporlarından kesitler verilerek raporlanmıştır.

\section{Bulgular}

Çalışmada elde edilen verilerin analizi değişim oranı kavramı ile ilgili öğretmen adaylarının "yüzdelik yorumu" ve "eğim yorumu" olmak üzere iki farklı düşünme biçimine sahip olduklarını ortaya koymaktadır. Bu iki farklı düşünme şekli grup raporlarından, öğretmen adaylarının etkinlik sonrası düşünme raporlarından kesitler ve örnekler verilerek her bir grup için ayrı ayrı sunulmaktadır.

\subsection{Grup-1'in Çözüm Süreci}

Grup-1 üyeleri ilk aşamada yüzdelik yorumunu, yani bir yıldaki nüfusun verilen bir önceki nüfusa göre yüzdelik olarak ne kadar arttığı fikrini kullanmışlardır. Ancak daha sonra grup üyeleri yıl aralıkları eşit verilmediği için buldukları yüzdelik değerlerle karşılaştırma yapmalarının yanlış olacağını düşünmüşlerdir. Bu durumda, öğretmen adayları ancak 10 yıl aralıklı verileri kullanarak yıl aralıklarını eşit yapabileceklerini düşünüp gerekli hesaplamaları yine yüzdelik yorumuyla yapmışlardır (bkz. Şekil 6).

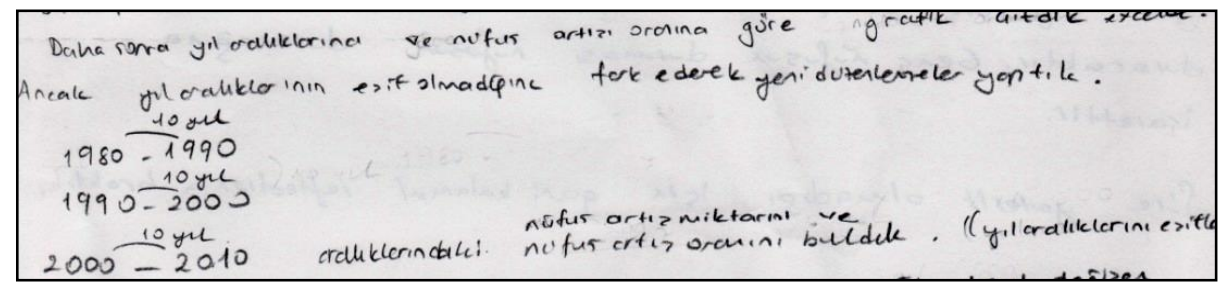

Şekil 6. Grup-1'deki katılımcıların değişim oranı kavramını yüzde ile ifade etmek için yıl aralıklarını eşitlemesi

$\mathrm{Bu}$ aşamada, sadece onlu yıllardaki verileri kullanma ve dolayısıyla diğer yıllara ait verileri kullanmama üzerine grup içi tartışmalar, Grup-1'i tüm verileri kullanabilecekleri yeni bir yöntem arayışına yönlendirmiştir. Yeni durumda, Grup-1 yıl aralıklarını daha kolay karşılaştırabilecekleri düşüncesiyle yıllık nüfus artış miktarını kullanmaya karar vermiştir. 
... Farklı açıdan bakarsak, nüfus artış oranını (hızını) yıllık nüfus artış miktarı olarak tanımlarsak; 1980-1985 arası nüfus artış hızı $=\frac{50660 \quad 45586}{19851980}=1014$ kişi/yıl (Grup1, Grup raporu)

Grup üyeleri ilk bakışta "nüfus artı̧̧ oranı (hızı)" ifadesini bir önceki nüfus verilerine oranla nüfusun yüzdelik olarak ne kadar arttı̆̆ şeklinde yorumlamış olup eşit olmayan yıl aralıklarını karşılaştırabilmek için yıllık nüfus artış miktarı (eğim) yorumuna yönelmişlerdir. Grup-1 üyelerinin düşünme süreçleri etkinlik sonrası düşünme raporlarına şu şekilde yansımışır:

...Öncelikle nüfus artış oranını nüfus artış miktarının başlangıçtaki nüfus miktarına oranı olarak tanımladık. Bu bize nüfusun \% olarak ne kadar arttı̆̆ın gösterecekti... Oranları bu tanıma göre hesaplayıp grafiğini çizdirdiğimizde sonuç çok anlaml gelmedi... Sorunun nüfus ölçüm aralıklarının sabit olmamasından kaynaklandiğını gördük. Artış oranlarını basitçe yıl sayısına bölerek de hesaplayamazdık çünkü artışlar katı alınarak ilerlediği için her sene aynı artış gözlenemezdi... Bir arkadaşımız yılların onar onar üç gruba ayrllabileceğini fark etti. Bu sefer eşit aralıklar elde ettiğimiz için sorun yaşamayacaktık. Hesaplarımızı buna göre tekrar yaptığımızda sadece üç veriden oluştuğu için grafikler hakkında çok fazla yorum yapamadık. Daha sonra arkadaşlarıma soruyu daha basit düşünmemizi önerdim... Nüfus artış oranını sadece senelik nüfus artış miktarı olarak hesapladık. Bu durumda nüfus artışının büyümeye etkisini yok saymış olduk. Her sayımdaki nüfus artışını sene farkına böldük. (ÖA1, Etkinlik sonrası düşünme raporu)

ÖA1'in ifadeleri, grubun süreçte yıllık artış miktarl fikrine (oranın eğim yorumu) yöneldiğini göstermekle birlikte “... nüfus artışının büyümeye etkisini yok saymış olduk." ifadesi grubun yıllık artış miktarı ifadesini bir oran olarak kabul etmede zorlandığını göstermektedir.

Öte yandan, Grup-1 üyelerinden ÖA2, grup olarak düşünme süreçlerini şu şekilde açıklamaktadır:

En son aşamada eğer biz yıllara göre nüfus değişimini gösteren bir grafik çizersek bu grafikteki herhangi bir noktanın eğimi bize o ylldaki oranı verecektir, diye düşündük... Problem çözümünü düşünürken ilk önce günlük hayatta nüfus artış oranının nasıl belirlendiğini düsündük ve aklıma ilk bir önceki seneye oranladı̆̆ımız durum geldi. Ancak bir başka yorumumuzda grafik kullandiğımızda o noktanın eğimini bularak oranı elde etmek oldu. İki yorum da çok kafamızı karıştırdı. Çünkü iki yorumun da aslında matematiksel olarak doğru olabileceğini düşünüyoruz. (ÖA2, Etkinlik sonrası düşünme raporu) 
ÖA2 raporunda nüfusun zamana bağlı değişiminin (eğimin) bir tür oran olduğunu verileri grafik üzerine aktardıktan sonra düşündüklerini; nüfus artış oranı ifadesinin günlük hayatta daha çok yüzdelik anlamda ifade edilmesinin onları yüzdelik olarak düşünmeye sevk ettiğini belirtmiştir. Grup-1 üyelerinin çalışma sürecinde nüfus artış oranı (hızl) ifadesini yıl-nüfus grafiğindeki ĕgim olarak yorumlamaktan uzun süre uzak durdukları söylenebilir. Yani öğretmen adayları başlangıçtan itibaren uzun bir süre "nüfus artış oranı (hızı)" ifadesini birimli oran (nüfus/yıl) olarak yorumlamamışlardır. Hatta öğretmen adaylarının değişim oranı kavramını "yüzdelik" ve "birimsiz oran" olarak yorumladıkları söylenebilir. Grup-1'deki öğretmen adayları yıl aralıklarının eşit olmamasından dolayı nüfusu karşılaştırmada yaşadıkları zorluğu yıl aralıklarını onar yıl alıp eşitleyerek yine yüzdelik yorumuyla devam ederek aşmaya çalışmışlardır. Bu grup için yıl aralıklarının eşit verilmemesi grup üyelerini birimli oran (eğim) yorumuna zorlayan önemli bir faktör olmuştur.

\subsection{Grup-2'nin Çözüm Süreci}

Üyelerinden ikisi yabancı uyruklu olan Grup-2, etkinliğin başlangıcından itibaren ĕgim yorumu ile düşünmüşlerdir. Bu çerçevede çözüm süreçlerinde öncelikle her bir yıl aralığındaki nüfus artış miktarını hesaplamış ve daha sonra da nüfus artış hızı karşılaştırması yapabilmek için her bir yıl aralığında yıllık nüfus artış miktarını verecek olan eğimi hesaplamışlardır.

1980-1985 arası nüfus artış hızı $=\frac{5066045586}{19851980}=1014$ kişi/yıl (Grup-2, Grup
raporu)

Grup-2'nin çözüm sürecinde eğim yorumuna nasıl karar verdiği ÖA4 ve ÖA5 tarafından etkinlik sonrası düşünce raporunda şöyle açıklanmıştır:

Nüfustaki değişim oranı (hızı) kısmını çözerken ilk önce yıl aralıklarındaki nüfus artışını, nüfus artış oranı (hızı) gibi yorumladık. Fakat yaptığımız bu hatanın hemen farkına vardık çünkü yıl aralıkları eşit değildi. Yani sadece nüfus artı̧̧ miktarına bakarak örneğin 1980-1990 yll aralı̆g ile 2009-2010 yll aralı̆̆ıı karşılaştırmak çok mantıksızdı. Bu nedenle her bir yıl aralığı için bize yıllık nüfus artış miktarını verecek olan eğimi hesaplamamı gerektiğimi fark ettik. (ÖA4, Etkinlik sonrası düşünme raporu)

ÖA4'ün açıklamaları grubun başlangıçta sadece nüfus artış miktarına göre karar vermeye çalıştığı, daha sonra yıl aralıkları eşit verilmediği için yıllık nüfus artışı fikrine yöneldiğini göstermektedir. Aynı gruptan ÖA5 ise grup olarak düşünme şekillerini şu şekilde açıklamıştır:

Illk önce tablodaki tüm verileri MS Excel'e girdik. Tablodaki verilere bakarak Türkiye nüfusunun 1980'den beri daima artış halinde olduğunu kolayca gözlemleyebiliriz. Bunu gözlemledikten sonra yıllar arasındaki artışları da bulduk. Tabi sadece artışa bakarak hangi yılda daha fazla nüfus artış hızı olduğunu 
söyleyemezdik. Çünkü ylllar arasındaki süre değişiyordu. Sağllklı bir yorum yapabilmek için yıllar arasındaki artış ile beraber ĕgimlerine de baktık. Ĕğimi daha büyük olan aralı̆̆ın nüfus artış hızı da en fazlaydı. (ÖA5, Etkinlik sonrası düşünme raporu)

Ayrıca, nüfustaki durağanlaşma ile ilgili soruyu cevaplamak için grup üyeleri tablodaki verileri kullanarak MS Excel programında zaman-nüfus grafiğini çizdirip bu grafiği en iyi temsil eden matematiksel fonksiyonunu bulmuşlardır. Bulunan bu ikinci dereceden fonksiyonun tepe noktasını türev kullanarak nüfusun durağanlaşmaya başlayacağı yıl tahmini olarak hesaplamışlardır. Grup-2 nüfusun zamana bağlı değişimini bir fonksiyon olarak düşünüp net bir yıl tahmini yaparak aşağıdaki çözümü ortaya koymuştur.

...Mevcut nüfus verisi en uygun $y=-11,786 x^{2}+47968 x-5 \times 10^{7}$ fonksiyonu ile ifade edilebilir. Nüfus ĕgimin sıfir olacağl noktada durağanlaşacă̆ iç̧in $\frac{d y}{d x}=-23 x+47968=0$ denklemi bize nüfusun dură̆anlaşmaya başlayacă̆ parabolün tepe noktasını verecektir. Sonuç $x=2035,99 \approx 2036$ çıkmaktadır. (Grup-2, Grup raporu)

\subsection{Grup-3'ün Çözüm Süreci}

Grup-3 üyeleri de Grup-1 gibi yüzde yorumuyla nüfus artış oranlarını hesaplamışlardır (bkz. Şekil 7). Grup-3 üyeleri nüfus artış oranını hesaplarken eğim yorumunu içeren yaklaşımı da dikkate aldıklarını belirtmişlerdir.

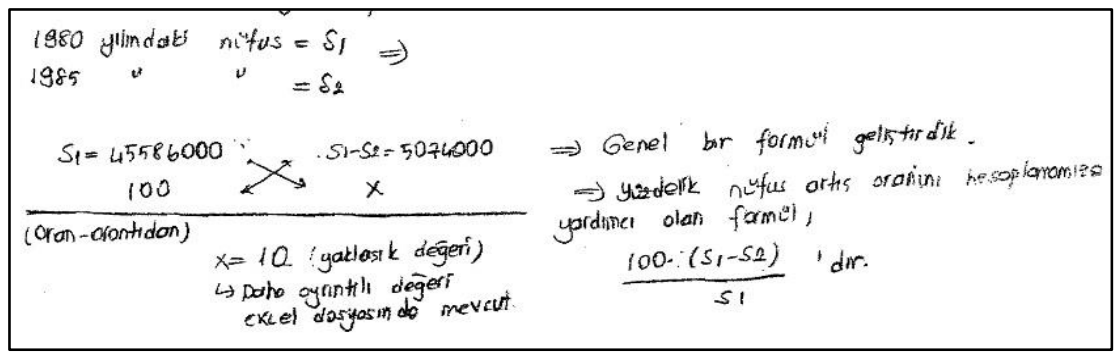

Şekil 7. Grup-3'ün çözümünü içeren grup raporundan bir kesit

$\mathrm{Bu}$ yaklaşıma göre nüfusun azlığı veya çokluğu nüfus artış oranını etkilemediğinden grup üyeleri bu yorumun doğru olamayacağını düşünmüştür. Grup-3 üyelerinden ÖA6 bu yaklaşımı kullanmama gerekçelerini etkinlik sonrası düşünce raporunda şöyle ifade etmiştir: 
...Mesela 50 milyon insanın 5 yılda 55 milyona ulaştığını düşünün. Potansiyel nüfusu göz önüne almazsak (yani sadece eğimi kullanırsak), nüfus artış oranı $\frac{55-50}{5}=1$ dir. Şimdi 100 milyon insanın 5 yılda 105 milyon insana ulaştı̆̆ı̆n

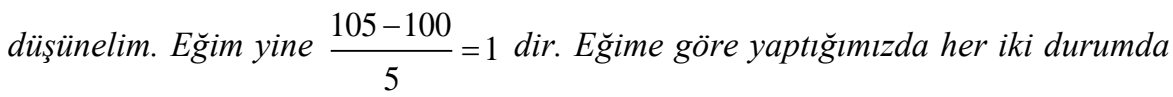
da nüfus artış oranı (hızl) aynı görünüyor. Ama aslında 50 milyon insan 5 yılda $\% 10$ artarken 100 milyon insan 5 yılda \%5 artmıştır. Yani potansiyel nüfus önemlidir. O yüzden aklımıza gelen ilk çözümü kullandık. (ÖA6, Etkinlik sonrası düşünce raporu)

Nüfustaki değişimi yüzdelik yorumuna göre açıklayan Grup-3, soruda yıl aralıkları eşit verilmediğinden yüzdelik değerleri nasıl karşılaştırmaları gerektiğine yönelik bir zorlukla karşılaşmıştır. Grup raporunda sunulan açıklamaya göre öğretmen adayları bu sorunu her bir aralık için buldukları artış yüzdesini yıl sayısına bölerek yıllık nüfus artış oranını hesaplayıp aşmaya çalışmışlardır. Grup-3'ün çözüm sürecini etkinlik sonrası düşünce raporunda grup üyelerinden biri şu şekilde açılamaktadır:

... Başlangıçta kafamızdaki "nüfus artış oranı (hızı)”, nüfustaki artış miktarının bir önceki nüfusa oranıydl. Fakat süreçte yll aralıklarının eşit verilmemesinden dolayı eğim ve yüzde yorumu arasında çelişkiye düştük. Bu iki yaklaşım arasında tercih yaparken zamanımızın büyük bir kısmını harcadık. Sonunda potansiyel nüfusun göz ardı edilemeyeceğine karar verdik ve şöyle bir formül kullandık: $x, y$ yılları arasında bir yıldaki nüfus artış oranı $=\% \frac{y \text { yılındaki nüfus }-x \text { yılındaki nüfus }}{x \text { yılındaki nüfus }} \cdot \frac{100}{y-x}$ (ÖA8, Etkinlik sonrası düşünce raporu)

Etkinlik sonrası düşünce raporu Grup-3'deki öğretmen adaylarının "nüfus artış oranı (hızı)" ifadesini anlamlandırmakta zorlandıkları göstermektedir. Kullanılan "artış oranı" ifadesi de öğretmen adaylarının nüfusun yüzdelik olarak ne kadar arttığı şeklinde anlamalarının daha baskın olduğunu görülmektedir. ÖA7, diğer grupların çözümlerini de göz önünde bulundurarak kendi çözümlerini aşağıdaki gibi değerlendirmiştir:

Ben bu problemin öğrencilerde kafa karışıklığı yaratabileceğini düşünüyorum, çünkü bende öyle oldu. Ben hâlâ nüfus artış oranını hesaplarken potansiyel nüfusu dikkate almamı gerektiğini düşünüyorum. Bu tarz bir soru gelse muhtemelen yine aynı şekilde çözmeyi düşünürdüm. (ÖA7, Etkinlik sonrası düşünce raporu)

Öte yandan ÖA8, grup tartışma sürecinde eğim ve yüzdelik yorumu arasında çelişki yaşadıklarını ve potansiyel nüfusun göz önünde bulundurulması gerektiğini düşünerek nüfus artış hızını yüzdelik olarak yorumlamaya karar verdiklerini ifade etmiştir. ÖA8, eğim yorumu ve uygulamadan sonra grup sunumları sırasında yapılan tartışmaların da etkisiyle etkinlik sonrası düşünce raporunda alternatif bir çözüm önermiştir. Ö8, 
raporunda bu çözüm bağlamında değişim oranı kavramı ve bu soruda eğim yorumunun kullanılmasıyla ilgili kafasında bulunan çelişkileri de şöyle açıklamıştı:

Aslında "oran” kelimesine takıldığımız için kullanmaya karar verdiğimiz bu yöntem (yüzde yorumu) sorunun ilk klsmı için uygun değildi, çünkü soru "19801985 yıllarl arasında ve diğer yıl aralıklarında nüfustaki "artış miktarl” nedir?" diyordu. Yani ikinci klsım oranları karşılaştırmamızı isterken, birinci klsım miktarları karşılaştırmamızı istiyordu. Bunun için, orana takılmadan önceki ilk yaklaşımımızı, ĕgim yorumuyla kullanmalıydık... Yalnız burada aklıma takılan başka bir soru var. Elimizdeki verilerde sabit bir yıl aralığ yok. Yıl aralıklarl 1 yll, 10 yll arasında değişiyor. Bu veriler için yll-nüfus grafiği çizerken bu grafiğin doğrusal olup olamayacă̆ını bilemeyiz. Örneğin bu grafik aşağıdaki gibi olabilir.

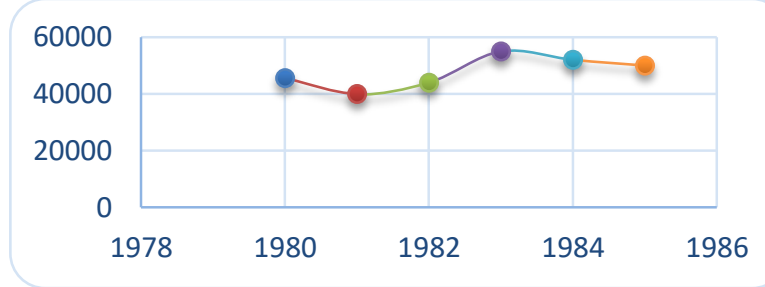

Bu durumda 1980-1985 yılları arasında birim yıldaki nüfus artış miktarını (1980, 45586) ve $(1985,50660)$ noktalarını birleştiren doğrunun eğimi olarak alamayız. Yani, eğimi sadece elimizde eşit zaman aralıklarıyla verilmiş nüfus bilgileri olduğu zaman kullanabileceğimizi düşünüyorum. Ama buradaki durumda eğim yaklaşımı ne kadar doğrudur bilemiyorum. (ÖA8, Etkinlik sonrası düşünce raporu)

ÖA8, eğim yaklaşımını kullanarak yaptığ1 alternatif çözümün doğru olup olmadığı konusunda tereddüt yaşamaktadır. 1980-1985 yılları arasındaki nüfus artışının doğrusal ilerlememiş olabileceğini grafik üzerinde açıklayarak burada eğime bakarak yorum yapmanın doğru olmayacağını, sebep olarak ise ĕgim yaklaşımının kullanılabilmesi için bu yıllar arasındaki nüfus değişiminin lineer olduğunu bilmemiz gerektiğini ifade etmektedir. $\mathrm{Bu}$ ifade ÖA8'in ortalama değişim oranı (sekant doğrusunun eğimi) kavramıyla ilgili zorluklarının olduğunu göstermektedir. Açıklamanın son cümleleri ÖA8'in "eğim (ortalama değişim oranl)" yaklaşımının sadece eşit aralıklı ve lineer fonksiyonlarda uygulanabileceği düşüncesine sahip olduğu söylenebilir. 
Tablo 1. Öğretmen Adaylarının Değişim Oranıyla İlgili Düşünme Biçimleri

Değişim oranını yüzde olarak yorumlama

(Birimsiz Oran)

$x, y$ yılları arasında nüfus artış oranı $\% \frac{y \text { yılındaki nüfus }-x \text { yılındaki nüfus }}{x \text { yılındaki nüfus }} \times 100$ dır. (Grup-1 \& Group-3)

Yıl aralıklarının eşit olmaması durumu için farklı düşünme biçimleri,

- $\quad$ Sadece 10'ar yıl aralıklı verileri alma. (Grup-1)

- $\quad x, y$ yılları arasında bir yıldaki (yıllık) nüfus artış oranı

$\% \frac{y \text { yılındaki nüfus }-x \text { yılındaki nüfus }}{x \text { yılındaki nüfus }} \times \frac{100}{y-x}$ (Grup 3$)$

Örneğin, 1980-1985 için,

$\frac{1980-1985 \text { arası nüfustaki artış miktarı }}{1980 \text { yılına ait nüfus }}=\frac{5074}{45586} \times 100 \approx \% 11,13$

$\mathrm{Bu}$ durumda bir yıldaki nüfus artış oranı ise $\% 2,23$ bulunur.
Değişim oranını eğim olarak

yorumlama (Birimli Oran)

Nüfus artış oranını (hızını)

yıllık nüfus artış miktarı, eğim

olarak tanımlama (Grup-2)

Örneğin, 1980-1985 arası

ortalama nüfus artış oranı (hızı)

$\frac{50660-45586}{1985-1980}=1014 \mathrm{kişi} / \mathrm{y} 1 \mathrm{l}$

olur.

\section{Tartışma ve Sonuç}

Çalışmada elde edilen verilerin analizi öğretmen adaylarının değişim oranı (hızı) ifadesini anlamlandırmakta zorlandıklarını ve çözüm süreçlerinde bu ifadeyi daha çok yüzdelik olarak yorumladıklarını göstermektedir. Grup-1 ve Grup-3'deki öğretmen adayları "zamana bağlı nüfus artış oranı (hızı)" ifadesini yüzdelik olarak yorumlamışlardır. Bu iki grubun iki değişkenden ziyade tek değişken olarak nüfus miktarına odaklanmalarından dolayı oran ifadesini direk olarak yüzde, yani birimsiz oran, şeklinde yorumladıkları söylenebilir. Grup-3'ün potansiyel nüfusun göz önünde bulundurulması gerektiğini 1srarla vurgulaması, grup üyelerinin bu soru bağlamında nüfusu zamana bağlı değişen bir fonksiyon olarak düşünmediklerini ve iki farklı değişkenin birbirine göre nasıl değiştiğini ifade eden eğimi bir tür oran olarak görmediklerini göstermektedir. Başka bir ifadeyle, zaman-nüfus bağlamında öğretmen adayları "yıllık nüfus artışı" olarak elde edilen değeri bir oran olarak değil miktar olarak görmüşlerdir. $\mathrm{Bu}$ durum öğretmen adaylarının üstel fonksiyonlarla modellenebilen bağlamlarda değişim oranı kavramını anlamlandırmakta ciddi zorluk yaşadıklarını göstermektedir. Grup-2 ise nüfus artış oranı ifadesini eğim yorumu ile düşünmüştür. Eğim yorumu, bu grubun iki farklı değişken olan zaman (yıl) ve nüfustaki değişimi birlikte ele alarak zamana bağlı nüfus fonksiyonu şeklinde düşünmelerine yardımcı olmuştur.

Değişim oranının iki farklı yorumu (yüzde yorumu ve eğim yorumu) matematiksel anlamda doğru olsa da çalışmada kullanılan problem bağlamındaki "nüfusun zamana bağlı değişim oranı" ifadesi matematiksel olarak yüzde yorumunu değil eğim (birimli oran) yorumunu kullanmayı gerektirmektedir. Çünkü bir değişkenin diğer bir değişkene bağlı olarak değişim oranı ifade edilmektedir. Confrey ve Smith (1994) bu soru bağlamında 
yüzde olarak kodlanan düşünme şeklini çarpımsal değişim oranı, eğim olarak kodlanan düşünme şeklini ise toplamsal değişim oranı olarak isimlendirmektedir. Bu iki yorum arasındaki matematiksel ilişki üstel fonksiyonlarda en açık şekilde gözlemlenmektedir. Örneğin başlangıç nüfusu $P_{0}$ olan bir ülkenin zamana bağlı nüfus fonksiyonunun $f(t)=P_{0} \cdot e^{0,02 t}$ ile temsil edildiğini düşünelim. Bu durumda eğim yorumuyla bakıldığında herhangi bir $t$ anındaki nüfusun değişim oranı $0,02 \cdot P_{0} \cdot e^{0,02 t}$ iken yüzde yorumu ile bakıldığında ise bu oran $\% 2$ 'dir. Birinci durum fonksiyonun birim zamanda kendisiyle orantılı olarak nasıl değiştiğini (birimli) ifade ederken, ikinci durum ise fonksiyonun kaç katına çıktığını veya yüzde kaç arttığını ifade etmektedir (birimsiz). Üstel fonksiyon ile modellenebilen bağlamlarda değişim oranı kavramının eğim (birimli oran) olarak yorumlanması yüzdelik veya "birimsiz oran" yorumuna göre daha zordur (Confrey \& Smith, 1994). Ayrıca bu tür durumlarda eğim (birimli oran) yorumu ortaya çıksa da öğrenciler bunu bir tür oran olarak görmeyebilmektedir. Nitekim bu çalışmada da, öğretmen adayları nüfus artış oranı (hızl) ifadesinden nüfusun bir önceki nüfusa oranla yüzdelik olarak ne kadar arttığını algılamışlardır. Bu sonuç Confrey ve Smith (1994) tarafından dile getirilen bazı bağlamlarda çarpımsal değişim oranının toplamsal değişim oranına kıyasla öğrenciler için daha doğal ve anlamlı bir yorum olabileceği bulgusunu desteklemektedir. Zaman-nüfus bağlamında yüzdelik yorumu öğrencilere daha anlamlı gelmekle birlikte öğretmen adaylarının yüzdelik yorumu ile eğim yorumu arasında tercih yapmaya çalıştıkları ve bu iki yorumu matematiksel olarak ilişkilendiremedikleri gözlemlenmiştir. Nitekim öğretmen adayları grup sunumları ve sınıf tartışması sonucunda da ortak bir sonuca ulaşamamışlardır. Diğer yandan, Teuscher ve Reys'in (2012) çalışmasında ortaya çıkan öğrencilerin lineer olmayan durumlarda, değişim oranı kavramını hesaplamakta, grafik üzerinde yorumlamakta ve gerçek hayatta anlamlandırmakta zorlandıkları bulgusu bu çalışma kapsamında öğretmen adaylarının muhtemel başka bir zorluğuna işaret etmektedir. Modelleme etkinliğinde sunulan verilerin lineer bir ilişki gösterip göstermediğinin aşikâr olmaması veya grafik gösterimi ile desteklenerek verilmemesi, öğretmen adaylarının değişim oranı kavramını yorumlamakta zorlanmalarının bir diğer sebebi olabilir. Nitekim Grup-3 üyelerinden ÖA8'in etkinlik sonrası düşünce raporunda "eğim (ortalama değişim oranı)" yaklaşımının sadece eşit aralıklı ve lineer fonksiyonlarda uygulanabileceğini iddia etmesi bu yorumu desteklemektedir.

$\mathrm{Bu}$ çalışmada, yüzde ve eğim yorumunun ortaya çıkması ve bu iki yorum arasında matematiksel ilişkinin anlaşılamamasının yanı sıra soruda değişim oranı (hızı) Türkçe ifadesinin anlaşılamaması veya farklı anlaşılması ile ilgili önemli bazı sorunlar da tespit edilmiştir. Zamana bağlı nüfus artış oranı (hızı) ifadesinden öğretmen adaylarının nüfusun bir önceki nüfusa oranla yüzdelik olarak ne kadar arttığını algılamış olmaları, değişim oranı kavramının doğasından kaynaklanan zorlukların yanında öğretim programlarında ve Türkçede bu kavramın ifade edilişi ve kullanışından kaynaklı olabilir. Yabancı uyruklu öğrencilerin bulunduğu ve sorunun İngilizce versiyonu üzerinde çalışan 
Grup-2'nin yüzde yorumunu hiç düşünmemiş olması da bu bulguyu güçlendirmektedir. İngilizcedeki "rate" ve "ratio" sözcükleri birimli ve birimsiz oran kavramları arasındaki farklılığ 1 açık bir şekilde ifade ederken; Türkçede bu farklılık eski ve yeni ortaokul matematik dersi öğretim programlarında "birimli oran" ve "birimsiz oran" şeklinde ifade edilmeye çalışılmakla birlikte programda farklı bağlamlarda birimli-birimsiz farkı vurgulanmadan genel olarak oran ifadesi kullanılmaktadır (TTKB, 2009, 2013a). Ayrica daha önce de belirtildiği gibi öğretim programlarında birimli ve birimsiz oran farkını açıklamak için kullanılan birkaç etkinlik dışında birimli oran kavramı üzerinde yeterince durulmaması ve oran kavramının genel olarak "birimsiz oran" örnekleri bağlamında ele alınması da duruma yeterince önem verilmediğinin bir göstergesidir. Nitekim bu çalışmada katılımcılar zaman (yıl)-nüfus grafiğindeki eğimi bir tür oran (birimli oran) olarak kabul etmekte zorlanmışlardır.

İngilizcede farklı iki çokluğun birlikte değişiminin analizini ifade eden "rate" kavramının Türkçe ifade edilişiyle ilgili matematik dersi ilköğretim ve ortaöğretim programlarında genel bir uyum ve bütünlük olmadığı göze çarpmaktadır. Eski ve yenilenen ortaokul matematik dersi öğretim programlarında "rate" kavramı için birimli oran ifadesi kullanılmaktadır (TTKB, 2009, 2013a). Ortaöğretim matematik dersi öğretim programlarına bakıldığında 2011 yılında revize edilen programda türev konusu bağlamında $h ı z$ sözcüğü kullanılmakta (TTKB, 2011, s. 312), 2013 yılında yenilenen programda ise "değişim oranı" ifadesi kullanılmaktadır (TTKB, 2013b). Bu durumdan kaynaklı olarak oran kavramının "birimsiz oran" ile sınırlanarak öğrenilmesi öğrencilerin türevi değişim oranı olarak yorumlayabilmesinde önemli bir engel teşkil edebilecektir. Birçok araştırmada dile getirilen öğrencilerin verilen bir fonksiyonun herhangi bir noktadaki değişim oranı nedir ifadesini anlamlandıramamasının bir nedeni de bu olabilir (Orton, 1983; White \& Mitchelmore, 1996). Oran, birimli oran ve birimsiz oran kavramları arasındaki farkın anlaşılması ileri düzey matematik konularına altyapı oluşturması bakımından oldukça önemlidir (Akar, 2009; Thompson, 1994a).

$\mathrm{Bu}$ çalışmada kullanılan model-oluşturma etkinliğinde hız-zaman bağlamı dışında bir bağlam kullanılmış olması öğretmen adaylarının değişim oranı ifadesini yorumlamakta zorlanmalarına sebep olmuş ve bu kavramla ilgili farklı düşünme şekillerini ortaya çıkarma konusunda etkili olmuştur. Bu durum Gravemeijer ve Doorman (1999), Herbert ve Pierce (2008) gibi araştırmacılar tarafından dile getirilen, öğrencilerin türev kavramlarının gerçek hayat yorumlarının hareket bağlamıyla sınırlı olması bulgusunu desteklemektedir. Veri tablosunda yıl aralıklarının eşit verilmemesi öğretmen adaylarını nasıl kıyaslama yapabilecekleri üzerine düşünmeye sevk ederek birim yıldaki artış miktarı (değişim oranı, eğim) fikrine yönlenmelerini sağlamıştır (örn., Grup-1). Zaman aralıkları eşit verildiği zaman, özellikle de aralıklar birer birim verildiğinde, birim zamandaki değişim açık bir şekilde verilmiş olacağından (ortalama) değişim oranı üzerine düşünme gerekliliği ortadan kalkmaktadır (Cooney ve ark., 2010, s. 28). Öğretmen adaylarında baskın bir şekilde "birimsiz oran" algısı fark edilmekle birlikte bu etkinlik bağlamında eşit verilmeyen yıl aralıkları öğrencileri yüzdelik yorumundan eğim yorumuna, yani birimli oran fikrine zorlayan önemli bir etken olmuştur. Öğretmen adaylarının çarpımsal ve toplamsal değişim oranı arasındaki matematiksel ilişkiyi anlamlandırmalarına ve hangi 
yorumu hangi durumlarda tercih etmeleri gerektiğini bilmelerine yardımcı olmak için bu çalışmada kullanılan model oluşturma etkinliği uygun devam etkinlikleriyle de desteklenerek kullanılabilir.

$\mathrm{Bu}$ çalışmanın bulguları, çalışmaya katılan dokuz ilköğretim matematik öğretmen adayı ve çalışmada kullanılan modelleme etkinliği bağlamı ile sınırlıdır. Çalışmada kullanılan problem bağlamı öğretmen adaylarının yüzdelik ve eğim yorumu arasındaki ilişkiyi ve farkı anlamakta zorlandıklarını ortaya koymuştur. Aynı problem durumu tablo verileriyle değil de grafik gösterimiyle sunulduğu durumda bile öğrencilerin düşünme biçimleri değişebilecektir. Bu nedenle, farklı bağlamlar içeren problemler kullanılarak yapılacak bu tür çalışmalar öğrencilerin değişim oranı kavramıyla ilgili düşünme biçimlerini daha geniş bir yelpazede ortaya koyabilmemiz açısından önemlidir. Ayrıca, problemin genelliği ve değişim oranı kavramının semantik yapısı ile ilgisini ortaya çıkaracak farklı gruplarla daha kapsamlı çalışmalar yapılması yararlı olacaktır. Örneğin değişim oranının "marjinal maliyet" olarak bilindiği ekonomi bağlamında veya "debi" olarak adlandırıldığı fizik bağlamında öğrenciler tarafindan nasıl yorumlandığı, yüzdelik yorumunun bu bağlamlarda da ortaya çıkıp çıkmadığı araştırmaya değerdir. Türkçede, İngilizce "rate" ve "ratio" olarak ifade edilen kavramlar arasındaki farklılığı net bir şekilde ortaya koyabilecek bir terminolojiye ihtiyaç olup olmadığı da böylelikle daha açık bir şekilde ortaya çıkabilecektir. Ayrıca, benzer bir sorunun İngilizce harici diğer dillerde de olup olmadığı, okul matematiği öğretim programlarında bu kavramların ne şekilde ele alındığı incelemeye değerdir. 


\section{Pre-service Elementary Mathematics Teachers' Ways of Thinking about Rate of Change in the Context of a Modeling Activity}

\section{Extended Abstract}

Rate of change is the most critical and inclusive conceptualization of the concept of derivative and it is often used in interpreting derivative in real-world situations (Stroup, 2002; Thompson, 1994b). Furthermore, rate of change concept is important for conceptually understanding the multiple representations and interpretations of derivative (Bingölbali, 2008; Cooney, Beckman \& Lloyd, 2010; Kendal \& Stacey, 2003; Taşar, 2010; Zandieh, 2000). Proper understanding of rate of change also helps students to identify and understand the family of functions that a function belongs to by considering the nature of covariational relationship between the variables (Cooney et al., 2010). On the other hand, students' weak understanding of rate of change can lead to difficulties in understanding various calculus concepts such as functions, derivative, integration, and differential equations (Bezuidenhout, 1998; Rowland \& Javanoski, 2004; Thompson, 1994b; Ubuz, 2007; White \& Mitchelmore, 1996).

Although the concept of rate of change is seen as critical in developing students' understanding of calculus concepts, understanding it and interpreting it in different context is not an easy task (Bingölbali, 2008; Herbert \& Pierce, 2012b; Teuscher \& Reys, 2012). Various studies have highlighted the difficulties that teachers and students have in conceptualizing rate of change such as confusing it with the arithmetic mean (Bezuidenhout, 1998; White \& Mitchelmore, 1996), difficulty in interpreting the meaning of it (Gökçek \& Açıkyıldız, 2016; Orton, 1983; White \& Mitchelmore, 1996), and confusing it with the amount of change only in the dependent variable (Rowland \& Javanoski, 2004; Zandieh \& Knapp, 2006). Moreover, two different interpretations of rate of change (additive rate of change and multiplicative rate of change) that are relevant depending on the context may cause some difficulties and misconceptions for students (Confrey \& Smith, 1994; Kertil, 2014). Research into students' and teachers' difficulties regarding rate of change has suggested several possible sources of these difficulties. For instance, this concept is not stressed in the curriculum and most textbooks (Bingölbali, 2008). Another source is having to do with studying the concept only in the motion context (Herbert \& Pierce, 2008, 2012).

By adopting the models and modeling perspective (MMP) (Lesh \& Doerr, 2003), this study investigated pre-service mathematics teachers' ways of thinking about rate of change in the context of a modeling task related to population growth of Turkey and involving multiplicative and additive conceptions of rate of change. As the study focused on a group of pre-service teachers' ways of thinking on a particular modeling task, it carries out the properties of a case study (Cohen, Manion \& Morrison, 2000). The study was carried out in an undergraduate course on mathematical modeling for prospective teachers. Being selected through convenience sampling, the participants were 9 prospective middle school mathematics teachers in their senior year in a public university. The main data sources 
consisted of the pre-service teachers' group solutions to the modeling activity, individual reflection papers written by each participant, and field-notes of the researchers. In analyzing data, qualitative content analysis method was employed (Yıldırım \& Şimşek, 2006) by using a coding list obtained from the literature (Confrey \& Smith, 1994; Thompson, 1994b).

The results showed that participants demonstrated two different ways of thinking about the expression "rate of change in population with respect to time": (i) percentage of change in population (i.e., multiplicative rate of change), and (ii) per year change in population (i.e., additive rate of change or slope). The pre-service teachers who preferred using the percentage interpretation indicated that they did not consider "yearly population change" as a rate or ratio. Rather, they conceived it as an amount of change. Only one group (two of the members were English speaking foreign students) consistently interpreted rate of change in its conventional form (i.e., additive rate of change). Even though "percentage" interpretation was dominant, some of the participants were directed to "per year change in population" interpretation as the year intervals in the problem context were not given with equal intervals. The results revealed about prospective teachers' difficulties in conceiving the difference and the mathematical relationship between "percentage" and "slope" interpretations. The results also revealed about the problematic aspect of the Turkish expression for "rate of change".

Pre-service teachers' way of thinking about rate of change as the percentage of change in the population confirms Confrey and Smith (1994) that multiplicative rate of change is more meaningful for students in some contexts that can be modeled by exponential functions. Furthermore, although pre-service teachers used the idea of slope or "yearly population change", they did not consider it as a rate of change and they had difficulty in explaining the mathematical relation between percentage or slope interpretations. This result confirms the prevalent finding in the literature that students' conceptions of rate of change are generally rooted in motion context (i.e., distance-time and/or velocity-time) and students have difficulties in transferring these conceptions into non-motion contexts (Bezuidenhout, 1998; Gravemeijer \& Doorman, 1999; Herbert \& Pierce, 2008; Wilhelm \& Confrey, 2004; Yoon et al., 2010; Zandieh \& Knapp, 2006). As also observed by Teuscher and Reys (2012), the data of the current study revealed that pre-service teachers had difficulties in interpreting rate of change in non-linear situations in the absence of a graphical representation. The pre-service teachers' difficulty in giving meaning to the rate of change and their preference of percentage interpretation may be because of the Turkish expression for this term. In Turkish, there is only one word (i.e., "oran") that corresponds to both rate and ratio. Also, the existing inconsistencies in the usage of Turkish expression for rate of change in the primary and secondary school mathematics curricula (TTKB, 2009, 2013b) may be another source of pre-service teachers' difficulties.

This study is limited in terms of reporting nine pre-service teachers' ways of thinking in a modeling activity involving population growth. More studies are needed to clarify students' ways of thinking about rate of change in different non-motion contexts (i.e., "marginal cost" 
in Economics, "flow rate" in Physics) for broadly describing the possible ways of student thinking and developing effective pedagogical principles. Additionally, we strongly suggest further research on clarifying the semantic aspects of rate of change concept and if there is a need for a new term in Turkish for expressing it.

\section{Kaynaklar/References}

Ärlebäck, J. B., Doerr, H. M., \& O’Neil, A. M. (2013). A modeling perspective on interpreting rates of change in context. Mathematical Thinking and Learning, 15(4), 314-336.

Akar, K. G. (2009). Oran konusunun kavramsal öğreniminde karşılaşılan zorluklar ve çözüm önerileri. E. Bingölbali ve M. F. Özmantar (Ed.), Illköğretimde karşılaşılan matematiksel zorluklar ve çözüm önerileri içinde (s. 263-285). Ankara: Pegem Akademi Yayıncilık.

Bezuidenhout, J. (1998). First year university students' understanding of rate of change. International Journal of Mathematical Education in Science and Technology, 29(3), 389-399.

Bingölbali, E. (2008). Türev kavramına ilişkin öğrenme zorlukları ve kavramsal anlama için öneriler. M. F. Özmantar, E. Bingölbali ve H. Akkoç (Ed.), Matematiksel kavram yanılgıları ve çözüm önerileri içinde (s. 223-255). Ankara: Pegem Akademi Yayıncilik.

Carlson, M., Jacops, S., Coe, E., Larsen, S., \& Hsu, E. (2002). Applying covariational reasoning while modeling dynamic events: A framework and a study. Journal for Research in Mathematics Education, 33(5), 352-378.

Coe, E. E. (2007). Modeling teachers' way of thinking about rate of change (Unpublished doctoral dissertation). Arizona State University, Tempe, AZ, the USA.

Cohen, L., Manion, L., \& Morrison, K. (2000). Research methods in education (5th edition). London: Routledge.

Confrey, J., \& Smith, E. (1994). Exponential functions, rates of change, and the multiplicative unit. Educational Studies in Mathematics, 26(2/3), 134-165.

Cooney, T. J., Beckmann, S., Lloyd, G. M., Wilson, P. S., \& Zbiek, R. M. (2010). Developing essential understanding of functions for teaching mathematics in grades 9 12. Reston, VA: National Council of Teachers of Mathematics.

Delice, A. ve Sevimli, E. (2016). Matematik eğitiminde çoklu temsiller. E. Bingölbali, S. Arslan ve İ. Ö. Zembat (Ed.), Matematik eğitiminde teoriler içinde (ss. 519-530). Ankara: Pegem Akademi Yayıncilık.

Doerr, H., \& Lesh, R. (2011). Models and modelling perspectives on teaching and learning mathematics in the twenty-first century. In G. Kaiser, W. Blum, R. Borromeo Ferri, \& G. Stillman (Eds.), International perspectives on the teaching and learning of mathematical modeling (pp. 247-268). Dordrecht, the Netherlands: Springer.

Doerr, H. \& O'Neil, A. M. (2012). A modeling approach to developing an understanding of average rate of change. CERME 7, Working Group 6, Retrieved December 22, 2010 from http://www.cerme7.univ.rzeszow.pl/WG/6/CERME7-Doerr\&ONeil.pdf 
Doorman, L. M., \& Gravemeijer, K. P. E. (2009). Emergent modeling: discrete graphs to support the understanding of change and velocity. ZDM-Mathematics Education, 41, 199-211.

English, L. D. (2003). Reconciling theory, research, and practice: A models and modeling perspective. Educational Studies in Mathematics, 54, 225-248.

Erbaş, A. K., Çetinkaya, B., Alacacı, C., Çakıroğlu, E., Aydoğan-Yenmez, A., Şen-Zeytun, A., Korkmaz, H., Kertil, M., Didiş, M. G., Baş, S. ve Şahin, Z. (2016). Lise matematik konuları için günlük hayattan modelleme soruları. Ankara: Türkiye Bilimler Akademisi.

Gökçek, T. ve Açıkyıldız, G. (2016). Matematik öğretmeni adaylarının türev kavramıyla ilgili yaptıkları hatalar. Turkish Journal of Computer and Mathematics Education, $7(1), 112-141$.

Gravemeijer, K., \& Doorman, M. (1999). Context problems in realistic mathematics education: A calculus course as an example. Educational Studies in Mathematics, 39, 111-129.

Herbert, S., \& Pierce, R. (2008). An "Emergent Model" for rate of change. International Journal of Computers for Mathematical Learning, 13, 231-249.

Herbert, S., \& Pierce, R. (2012). Revealing educationally critical aspects of rate. Educational Studies in Mathematics, 81, 85-101.

Hoffkamp, A. (2011). The use of interactive visualizations to foster the understanding of concepts of calculus: design principles and empirical results. ZDM Mathematics Education, 43, 359-372.

Johnson, H. L. (2012). Reasoning about variation in the intensity of change in covarying quantities involved in rate of change. Journal of Mathematical Behavior, 31, 313-330.

Kelly, A. E. (2004). Design research in education: Yes, but is it methodological? Journal of the Learning Sciences, 13, 115-128.

Kendal, M., \& Stacey, K. (2003). Tracing learning of three representations with the differentiation competency framework. Mathematics Education Research Journal, $15(1), 22-41$.

Kertil, M. (2014). Pre-service elementary mathematics teachers' understanding of derivative through a model development unit (Unpublished doctoral dissertation). Middle East Technical University, Ankara, Turkey.

Lehrer, R., \& Schauble, L. (2007). A developmental approach for supporting the epistemology of modeling. In W. Blum, P. L. Galbraith, H-W. Henn, \& M. Niss (Eds.), Modeling and applications in mathematics education (pp. 153-160). New York, NY: Springer.

Lesh, R. (2010). Tools, researchable issues \& conjectures for investigating: what it means to understand statistics (or other topics) meaningfully. Journal of Mathematical Modeling and Application, 1(2), 16-48.

Lesh, R., Doerr, H. M., Carmona, G., \& Hjalmarson, M. (2003). Beyond constructivism. Mathematical Thinking and Learning, 5, 211-233. 
Lesh, R., Cramer, K., Doerr, H. M., Post, T., \& Zawojewski, J. S. (2003). Model development sequences. In R. Lesh, \& H. M. Doerr (Eds.), Beyond constructivism: Models and modeling perspectives on mathematics problem solving, learning, and teaching (pp. 3-33). Mahwah, NJ: Lawrence Erlbaum.

Lesh, R., \& Doerr, H. M. (2003). Foundations of a models and modeling perspective on mathematics teaching, learning, and problem solving. In R. Lesh, \& H. M. Doerr (Eds.), Beyond constructivism: Models and modeling perspectives on mathematics problem solving, learning, and teaching (pp. 3-33). Mahwah, NJ: Lawrence Erlbaum.

Lesh, R., \& Harel, G. (2003). Problem solving, modelling and local conceptual development. Mathematical Thinking and Learning, 5(2\&3), 157-189.

Lesh, R., Hoover, M., Hole, B., Kelly, A., \& Post, T. (2000). Principles for developing thought-revealing activities for students and teachers. In R. Lesh, \& A. Kelly (Eds.), Handbook of research design in mathematics and science education (pp. 591-645). Hillsdale, NJ: Lawrence Erlbaum.

Lesh, R. A., Kelly, A. E., \& Yoon, C. (2008). Multitiered design experiments in mathematics, science, and technology education. In A. E. Kelly, R. A. Lesh, \& J. Y. Baek (Eds.), Handbook of design research methods in education (pp. 131-148). New York, NY: Routledge.

Orton, A. (1983). Students' understanding of differentiation. Educational Studies in Mathematics, 14, 235-250.

Rowland, D. R., \& Jovanoski, Z. (2004). Student interpretation of the terms in first-order ordinary differential equations in modeling contexts. International Journal of Mathematical Education in Science and Technology, 35(4), 505-516.

Schorr, R. Y., \& Lesh, R. (2003). A modeling approach for providing teacher development. In R. Lesh, \& H. M. Doerr (Eds.), Beyond constructivism: Models and modeling perspectives on mathematics problem solving, learning, and teaching (pp. 159-174). Mahwah, NJ: Lawrence Erlbaum.

Sriraman, B. (2006). Conceptualizing the model-eliciting perspective of mathematical problem solving. In M. Bosch (Ed.), Proceedings of the Fourth Congress of the European Society for Research in Mathematics Education (CERME 4) (Vol. 1, pp. 1686-1695). Sant Feliu de Guíxols, Spain: FUNDEMI IQS, Universitat Ramon Llull.

Stroup, W. (2002). Understanding qualitative calculus: A structural synthesis of learning research. International Journal of Computers for Mathematical Learning, 7, 167-215.

Stump, S. (1999). Secondary mathematics teachers' knowledge of slope. Mathematics Education Research Journal, 11(2), 124-144.

Talim ve Terbiye Kurulu Başkanlığı [TTKB]. (2009). Illköğretim matematik dersi 6-8. sinıflar ögretim program ve kılavuzu. Ankara: Devlet Kitapları Müdürlüğü.

Talim ve Terbiye Kurulu Başkanlığı [TTKB]. (2011). Ortaögretim matematik (9, 10, 11 ve 12. sinıflar) dersi öğretim programı. Ankara: Devlet Kitapları Müdürlüğü.

Talim ve Terbiye Kurulu Başkanlığ [TTKB]. (2013a). Ortaokul matematik dersi (5, 6, 7 ve 8. sinıflar) ögretim programı. Ankara: Devlet Kitapları Müdürlüğü.

Talim ve Terbiye Kurulu Başkanlığı [TTKB]. (2013b). Ortä̈gretim matematik dersi (9, 10, 11 ve 12. sınıflar) ögretim programı. Ankara: Devlet Kitapları Müdürlüğü. 
Taşar, M. F. (2010). What part of the concept of acceleration is difficult to understand: The mathematics, the physics, or both? ZDM-Mathematics Education, 42, 469-482.

Teuscher, D., \& Reys, R. E. (2012). Rate of change: AP calculus students' understandings and misconceptions after completing different curricular paths. School Science and Mathematics, 112, 359-376.

Thompson, P. W. (1994a). Images of rate and operational understanding of the fundamental theorem of calculus. Educational Studies in Mathematics, 26, 229-274.

Thompson, P.W. (1994b). The development of the concept of speed and its relationship to concepts of rate. In G. Harel, \& J. Confrey (Eds.), The development of multiplicative reasoning in the learning of mathematics (pp. 181-236). New York, NY: State University of New York Press.

Ubuz, B. (2007). Interpreting a graph and constructing its derivative graph: Stability and change in students' conceptions. International Journal of Mathematical Education in Science and Technology, 38(5), 609-637.

White, P., \& Mitchelmore, M. (1996). Conceptual knowledge in introductory calculus. Journal for Research in Mathematics Education, 27(1), 79-95.

Wilhelm, J. A., \& Confrey, J. (2003). Projecting rate of change in the context of motion onto the context of money. International Journal of Mathematical Education in Science and Technology, 34(6), 887-904.

Yıldırım, A. ve Şimşek, H. (2006). Sosyal bilimlerde nitel araştırma yöntemleri (5. Baskı). Ankara: Seçkin Yayıncılık.

Yoon, C., Dreyfus, T., \& Thomas, M. O. J. (2010). How high is the tramping track? Mathematising and applying in a calculus model-eliciting activity. Mathematics Education Research Journal, 22(1), 141-157.

Zandieh, M. J. (2000). A theoretical framework for analyzing student understanding of the concept of derivative. In E. Dubinsky, A. Schoenfeld, J. J. Kaput, \& C. Kesel (Eds.), Research in collegiate mathematics education (pp. 103-127). Providence, RI: American Mathematical Society.

Zandieh, M. J., \& Knapp, J. (2006). Exploring the role of metonymy in mathematical understanding and reasoning: the concept of derivative as an example. Journal of Mathematical Behavior, 25, 1-17.

\section{Kaynak Gösterme}

Kertil, M., Erbaş, A. K. ve Çetinkaya, B. (2017). İlköğretim matematik öğretmen adaylarının değişim oranı ile ilgili düşünme biçimlerinin bir modelleme etkinliği bağlamında incelenmesi. Türk Bilgisayar ve Matematik Eğitimi Dergisi, 8(1), 188-217.

\section{Citation Information}

Kertil, M., Erbaş, A. K. \& Çetinkaya, B. (2017). Pre-service elementary mathematics teachers' ways of thinking about rate of change in the context of a modeling activity. Turkish Journal of Computer and Mathematics Education, 8(1), 188-217. 
Ek 1. Çalışmada kullanılan Gelecek Yüzyılda Türkiye başlıklı modelleme etkinliği (Erbaş ve ark., 2016)

T.C. Kalkınma Bakanlığı, gelecek yüzyıl için stratejik planlar yapmaktadır. Bu çerçevede, Türkiye nüfusunun yıllara göre nasıl değiştiği ve önümüzdeki 100 yıl içerisinde demografik yapının nasıl farklılaşacağı gelecekte yapılacak yatırım planlarını yönlendirmede belirleyici bir etkendir. Çünkü, mevcut durum gözetilerek yapılan yatırımlar yıllar sonra nüfus yapısındaki değişmeden dolayı kullanımsız kalabilmektedir. Bakanlık yetkilileri sizden aşağıdaki sorular doğrultusunda bir rapor hazırlamanızı istemektedir. Raporda, Tablo 1'de geçmiş yıllardaki nüfus değişiminin incelenerek gelecekteki nüfus yapısının nasıl oluşabileceği konusu irdelenmelidir.

1. Türkiye'nin nüfus artışı yıllara göre nasıl değişmektedir? Nüfustaki artışta nasıl bir değişim söz konusudur?

a. 1980-1985 yılları arasında ve diğer yıl aralıklarında nüfustaki artış miktarı nedir?

b. Zamana bağlı ortalama nüfus artış oranının (hızının) en yüksek ve en düşük olduğu yıl aralıkları hangileridir?

c. 2000 yılındaki (zamana bağlı) nüfus artış oranı (hızı) yaklaşık olarak nedir?

2. Bazı uzmanlar gelecekte Türkiye nüfusunun durağanlaşacağını iddia ediyorlar. Sizce böyle bir durum söz konusu mudur? Durağanlaşma olacaksa bunun ne zaman gerçekleşmesi beklenebilir?

Tablo 1. Yaş grubuna göre yıllar bazında Türkiye Cumhuriyeti nüfus verileri

\begin{tabular}{cccccc}
\hline \multirow{2}{*}{ Yıllar } & Nüfus $(\times \mathbf{1 . 0 0 0})$ & \multicolumn{4}{c}{ Yaş grupları } \\
\cline { 3 - 6 } & & $\mathbf{0 - 1 9}$ & $\mathbf{2 0 - 3 9}$ & $\mathbf{4 0 - 5 9}$ & 60 ve üzeri \\
\hline $\mathbf{1 9 8 0}$ & 45.586 & 22.556 & 13.745 & 6.756 & 2.529 \\
$\mathbf{1 9 8 5}$ & 50.660 & 24.467 & 15.015 & 7.922 & 3.256 \\
$\mathbf{1 9 9 0}$ & 55.971 & 25.981 & 17.500 & 8.456 & 4.034 \\
$\mathbf{2 0 0 0}$ & 67.800 & 27.438 & 22.458 & 12.215 & 5.689 \\
$\mathbf{2 0 0 7}$ & 70.786 & 24.938 & 23.604 & 15.176 & 7.068 \\
$\mathbf{2 0 0 8}$ & 71.557 & 24.996 & 23.927 & 15.551 & 7.083 \\
$\mathbf{2 0 0 9}$ & 72.641 & 25.133 & 24.225 & 15.832 & 7.451 \\
$\mathbf{2 0 1 0}$ & 73.724 & 25.155 & 24.482 & 16.265 & 7.822 \\
\hline
\end{tabular}

